\title{
Diversity and Distribution of Mid- to Late-Stage Phyllosomata of Spiny and Slipper Lobsters (Decapoda: Achelata) in the Mexican Caribbean
}

\author{
Rubén Muñoz de Cote-Hernández ${ }^{\dagger}$, Patricia Briones-Fourzán * ${ }^{*}$, Cecilia Barradas-Ortiz, Fernando Negrete-Soto \\ and Enrique Lozano-Álvarez
}

check for updates

Citation: Muñoz de Cote-Hernández, R.; Briones-Fourzán, P.;

Barradas-Ortiz, C.; Negrete-Soto, F.; Lozano-Álvarez, E. Diversity and Distribution of Mid- to Late-Stage Phyllosomata of Spiny and Slipper Lobsters (Decapoda: Achelata) in the Mexican Caribbean. Diversity 2021, 13, 485. https://doi.org/10.3390/ d13100485

Academic Editor: Bert W. Hoeksema

Received: 31 August 2021

Accepted: 1 October 2021

Published: 5 October 2021

Publisher's Note: MDPI stays neutral with regard to jurisdictional claims in published maps and institutional affiliations.

Copyright: (c) 2021 by the authors. Licensee MDPI, Basel, Switzerland. This article is an open access article distributed under the terms and conditions of the Creative Commons Attribution (CC BY) license (https:// creativecommons.org/licenses/by/ $4.0 /)$.
Unidad Académica de Sistemas Arrecifales, Instituto de Ciencias del Mar y Limnología, Universidad Nacional Autónoma de México, Puerto Morelos 77580, Mexico; rub.hhe.n@gmail.com (R.M.d.C.-H.);

barradas@cmarl.unam.mx (C.B.-O.); fnegrete@cmarl.unam.mx (F.N.-S.); elozano@cmarl.unam.mx (E.L.-Á.)

* Correspondence: briones@cmarl.unam.mx

+ Current address: Grupo Interdisciplinario de Gestión Ambiental, A.C., Ciudad de México 04909, Mexico.

\begin{abstract}
Achelata (Palinuridae and Scyllaridae) have a flat, transparent, long-lived planktonic larva called phyllosoma, which comprises multiple stages and has a duration from a few weeks (some scyllarids) to $>20$ months (some palinurids). The larval development of many Achelata occurs in oceanic waters, where conventional plankton nets usually collect the early- to mid-stages but not the later stages, which remain poorly known. We examined the diversity and distribution of mid-and late-stage phyllosomata in the oceanic waters of the Mexican Caribbean, where the swift Yucatan Current is the dominant feature. The plankton samples were collected at night with a large mid-water trawl in autumn 2012 (55 stations) and spring 2013 (34 stations). In total, we obtained 2599 mid- and late-stage phyllosomata (1742 in autumn, 857 in spring) of five palinurids (Panulirus argus, Panulirus guttatus, Panulirus laevicauda, Palinurellus gundlachi, Justitia longimana) and three scyllarids (Parribacus antarcticus, Scyllarides aequinoctialis, Scyllarus chacei). Overall, the mid-stages were $\sim 2.5$ times as abundant as the late stages. The palinurids far outnumbered the scyllarids, and P. argus dominated over all the other species, followed at a distance by P. guttatus. The densities of all the species were generally low, with no clear spatial pattern, and the phyllosomata assemblage composition greatly overlapped between seasons. These results suggest the extensive mixing of the organisms entrained in the strong Yucatan Current, which clearly favors the advection of the phyllosomata in this region despite the presence of some local sub-mesoscale features that may favor short-term retention.
\end{abstract}

Keywords: decapods; spiny lobsters; slipper lobsters; phyllosoma; Caribbean Sea; Yucatan Current

\section{Introduction}

The decapod crustacean infraorder Achelata comprises two families: Palinuridae (spiny lobsters) and Scyllaridae (slipper lobsters) [1,2]. Palinurids are characterized by their long and spiny second antennae, whereas the second antennae of scyllarids are modified as a hinged series of five flat plates. Both families share a distinctive type of planktonic, transparent larva called "phyllosoma" (plural: phyllosomata), which differs broadly in morphology from the benthic juveniles and adults. The term phyllosoma ("leaf body" in Greek) refers to the extremely flattened body of this larva. The duration of the larval phase varies with species but may encompass 4 to 22 months in Palinuridae and 30 days to 9 months in Scyllaridae [3,4].

The adaptations of phyllosomata to a long life in oceanic waters include a virtually transparent body that helps to avoid predation and the development of long and narrow pereopods with numerous setae and exopods that are used for flotation and to swim well enough to catch and retain prey $[3,5]$. The final stage metamorphoses into a nektonic postlarva, known as puerulus in Palinuridae and nisto in Scyllaridae, which swims back 
to the coastal benthic habitats where it settles [3,4]. Based on their size and degree of development, phyllosomata are grouped into different stages, each of which can encompass one or more instars [6]. The number of stages depends on the degree of morphological differentiation and the duration of the larval phase. The early stages can be more similar between species, but, as they grow, morphological changes are useful for identification purposes [3,7].

In the wider Caribbean region, adult populations of 13 species of Achelata occur (five Palinuridae and eight Scyllaridae) [8,9]. Of these species, the complete larval series is known for six: Panulirus argus [10,11], Justitia longimana [12], Scyllarus americanus [13], Scyllarus depressus [14], Scyllarus chacei [15], and Scyllarus planorbis [16]. The incomplete larval series is known for Panulirus guttatus [17,18], Panulirus laevicauda [19], Palinurellus gundlachi [20], Scyllarides aequinoctialis [21], Scyllarides nodifer, and Parribacus antarcticus [22,23]. There are no data regarding the larval development of Bathyarctus faxoni. One palinurid, $P$. argus, is a major fisheries resource throughout the region [24], whereas P. guttatus, P. laevicauda, S. aequinoctialis, P. antarcticus, and $S$. nodifer constitute minor fishing resources of varying importance in different countries [8,9].

The distribution of the Achelata species is determined by factors such as their larval duration, the survival rate of subsequent larval stages, their behavior and capacity to swim vertically, as well as the influence of local and regional oceanic processes $[3,6]$. The longer the larval duration, the greater the potential for dispersal via ocean currents [25]. However, despite limited swimming abilities, phyllosomata can control their vertical position in the water column, which may modulate the range of dispersion. Ontogenetic behavioral changes of phyllosomata may result in the stratification of different larval stages [26-28]. Regardless, phyllosomata spend most of their planktonic life in reasonably well-illuminated regions, as indicated by their eye structure [29], and they can only partially control their dispersion, which is mainly determined by the ocean currents $[3,6,30]$. These currents influence the connectivity and flow of larvae among different areas, although short- or long-term larval retention may occur in mesoscale processes [31,32].

Larval retention and dispersion dynamics may impact the distribution and abundance of phyllosomata [33-35], with important implications for the regional larval biodiversity. Processes of postlarval recruitment to coastal habitats may underlie fluctuations in the abundance of adult populations, and understanding these processes requires extensive information on the distribution of larvae $[3,36]$. In the Mexican Caribbean, studies addressing the diversity and distribution of phyllosomata have mainly obtained information on the early- to mid-stages, with little knowledge about the late stages [37-41]. The aim of the present study was to investigate the diversity and distribution of the mid- to late-stage phyllosomata of spiny and slipper lobsters along the Mexican Caribbean in two contrasting seasons in order to increase insight into the larval dynamics and connectivity of Achelata in the wider Caribbean region.

\section{Materials and Methods}

\subsection{Study Area}

The study area is in the NW Caribbean Sea, off the coast of the state of Quintana Roo (Mexico), from the shelf brake to approximately $100 \mathrm{~km}$ offshore. Along this coast, the continental shelf is very narrow ( $<10 \mathrm{~km}$ in general, but $<3 \mathrm{~km}$ in many parts), and depth increases rapidly a short distance from the shore [42]; therefore, our samplings were conducted almost exclusively in oceanic waters (Figure 1). In the NW Caribbean Sea, the Cayman Current flows from the Caribbean basin in an E-W direction and arrives almost perpendicular to the coast close to the southern sector of our study area. There, it veers north and becomes the Yucatan Current, which flows parallel to the coast and reaches its maximum velocities (up to $3 \mathrm{~m} \mathrm{~s}^{-1}$ ) in the Yucatan Channel. Upon entering the Gulf of Mexico, it turns into the Loop Current [43]. The velocity of the Yucatan Current is modulated by the passage of cyclonic and anticyclonic eddies and by the latitude of impingement of the Cayman Current $[42,44,45]$. Moreover, a coastal counter-current and a persistent 
sub-mesoscale eddy south of Cozumel Island have been repeatedly reported [42,46-48]. The dynamic complexity of this current system has important biological implications, with some areas favoring larval retention and others favoring larval advection [42,48] (see Section 3).

(a)

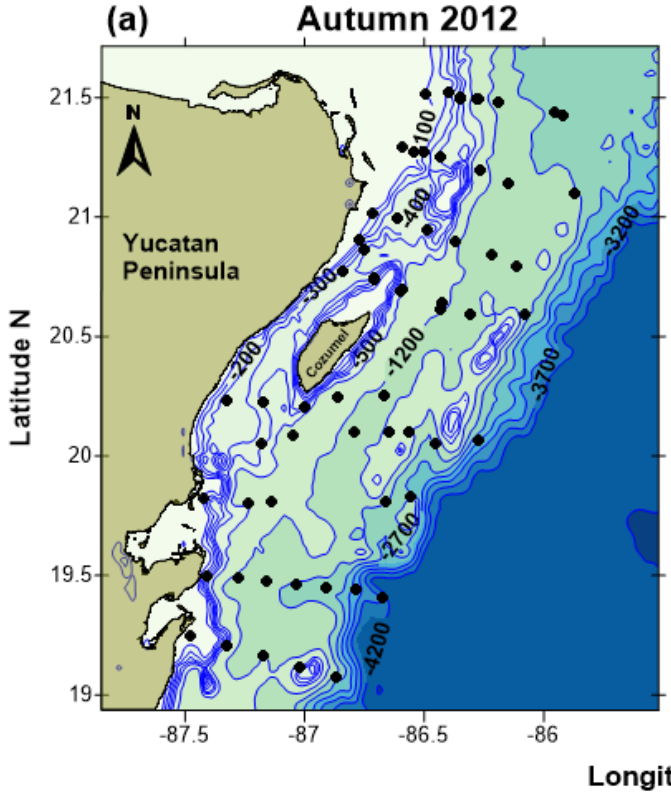

(b)

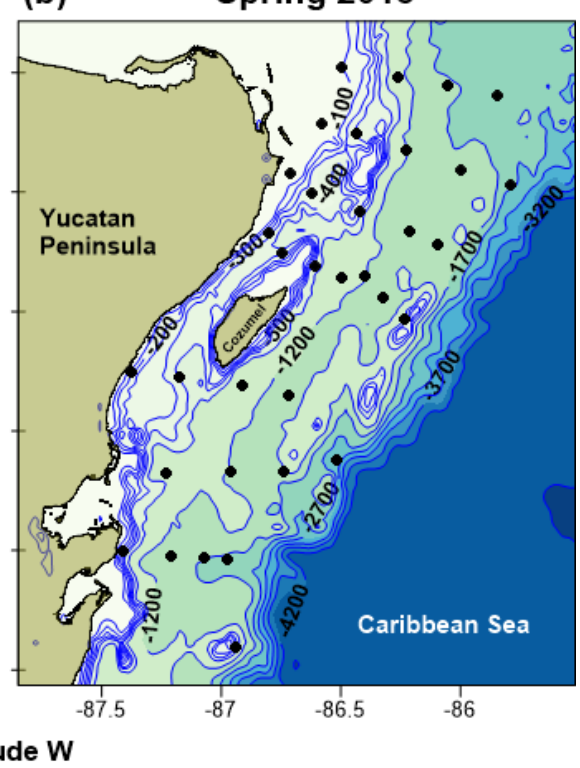

Figure 1. Study area showing location of plankton sampling stations (black dots) during (a) the autumn 2012 cruise and (b) the spring 2013 cruise.

\subsection{Larval Sampling and Identification}

Plankton samples were obtained during a research project addressing the location of metamorphosis zones of $P$. argus and P. guttatus and the nutritional condition of $P$. argus during the phyllosoma-puerulus-juvenile transition [48-51]. Sampling was conducted in numerous stations located along several transects perpendicular to the shelf break over oceanic waters during two oceanographic cruises in UNAM's R/V Justo Sierra, "Metamorfosis 1", conducted in autumn 2012 (13-24 November; 55 stations) and "Metamorfosis 2", conducted in spring 2013 (4-14 April; 38 stations). Hereafter, these cruises will be referred to as the "autumn cruise" and the "spring cruise", respectively (Figure 1).

Samples were obtained with two different nets used simultaneously: a larger midwater Tucker trawl (effective mouth area: $9 \mathrm{~m}^{2}$; length: $12 \mathrm{~m}$; mesh size: $10 \mathrm{~mm}$ ) primarily designed to collect late-stage phyllosomata, and a smaller neuston net (mouth area: $1.5 \mathrm{~m}^{2}$; length: $3 \mathrm{~m}$; mesh size: $3 \mathrm{~mm}$ ) primarily designed to collect swimming postlarvae of spiny lobsters $[48,49]$. The Tucker trawl was towed from stern at depths of 5-15 $\mathrm{m}$ and was fitted with a Sea-Bird SBE39 data logger to record time, depth, and temperature during the tow. The neuston net was towed from starboard approximately mid-ship within the uppermost meter of the water column. Tows were conducted against the prevailing current for 30-35 min at an average speed of $1.3 \mathrm{~m} \mathrm{~s}^{-1}$. Samples were taken exclusively during the hours of darkness (i.e., between $1 \mathrm{~h}$ after sunset and $1 \mathrm{~h}$ before sunrise) to increase the chances of catching phyllosomata, which tend to concentrate in the top $25 \mathrm{~m}$ of the water column in dark nights [27,52-54].

Surface geostrophic current fields during each cruise were derived from satelliteobtained sea surface dynamic altimetry data obtained from the Archiving, Validation, and Interpretation of Satellite Oceanographic data (AVISO). Results on hydrographic analyses and geostrophic flow velocities obtained from CTD (Conductivity, Temperature and Depth) profiles carried out during the day along the same transects in which larval sampling took place during the night were reported by Briones-Fourzán et al. [48]. 
Upon retrieving the nets, the fresh plankton were immediately examined for phyllosomata, which were preserved in $80 \%$ ethanol. In the laboratory, the larvae were identified and staged using specialized literature for palinurids: P. argus [10,11], P. guttatus [17], P. larvicauda [19], J. longimana [12], and P. gundlachi [20], and for scyllarids: S. americanus [13], S. depressus [14], S. chacei [15], S. planorbis [16], S. nodifer and S. aequinoctialis [15,21], and P. antarcticus $[22,23,55,56]$. To aid in phyllosomata identification and staging, the following measurements were taken under a stereoscopic microscope: total body length (BL), from the anterior margin of the cephalic shield between the eyestalks to the posterior end of the pleon; cephalic length (CL), from the anterior to the posterior margin of the cephalic shield; and cephalic width (CW), measured at the widest part of the cephalic shield [11,18]. To distinguish between similar stages of P. argus, P. guttatus, and P. laevicauda, we also used several ratios between these and other measurements (e.g., distance between mouth parts, see [17]). To distinguish between similar scyllarid species, we followed the keys provided by Robertson [15].

Earlier papers reported 11 larval stages for P. argus (e.g., [10,53]); however, Goldstein et al. [11] obtained the complete larval development of $P$. argus in culture, recognizing only 10 stages prior to metamorphosis. Therefore, we followed Goldstein et al. [11] to stage phyllosomata of $P$. argus. In the case of P. guttatus, Goldstein et al. [18] also obtained stages I-IX (which they considered the subfinal stage) of P. guttatus in culture, but their article was not available at the time our study was conducted. Instead, we followed Baisre and Alfonso [17], who suggested 11 stages for this species.

\subsection{Data Analyses}

Because phyllosomata are highly diluted, individual stages of a given species may be scarce or completely absent in some sampling stations; therefore, a common procedure to analyze their distribution consists of grouping them into three categories: early-stage, mid-stage, and late-stage phyllosomata $[30,41,52,57,58]$. We used the following criteria for this categorization: early stages: appendages not well developed and with no exopods, not all pereopods present, antennules longer than or equal in length to antennae; midstages: exopods without setae in almost all appendages, antennae may exceed the length of antennules, abdomen starting to segment or already segmented, pleopods and uropods beginning to develop; late stages: appendages well developed with exopods and setae present, all pereopods present and well developed, antennae exceed length of antennules, abdomen well segmented, pleopods and uropods completely developed, gills (when present) may appear as papillae, unilobed buds, or completely developed bilobed buds. For P. gundlachi, we also considered the degree of extension of the cephalic shield over the thorax (see [20]). These categories do not necessarily include the same stages for all species (Table 1).

Table 1. Categorization of individual phyllosomata stages of eight Achelata species into early stages, mid stages, and late stages.

\begin{tabular}{cccc}
\hline Species & Early Stages & Mid Stages & Late Stages \\
\hline Panulirus argus & I-III & IV-VIII & IX-X \\
Panulirus guttatus & I-III & IV-VIII & IX-XI \\
Panulirus laevicauda & I-III & IV-VIII & IX-XI \\
Palinurellus gundlachi & I-V & VI-VIII & IX-XII \\
Justitia longimana & I-IV & V-VIII & IX-X \\
Parribacus antarcticus & I-V & VI-VIII & IX-XI \\
Scyllarides aequinoctialis & I-V & VI-IX & X-XI \\
Scyllarus chacei & I-III & IV-V & VI-VII \\
\hline
\end{tabular}

To examine the spatial distribution of larvae, the number of mid-and late-stage larvae of each species was standardized to $1000 \mathrm{~m}^{3}$ of filtered water. Densities were estimated only for samples taken with the mid-water Tucker trawl, which caught $94 \%$ of all phyllosomata. 
The filtered volume $(\mathrm{V})$ was estimated with the equation $\mathrm{V}=\mathrm{D} \times \mathrm{A}$, where $\mathrm{D}$ is distance travelled, derived from the ship's speed $\left(\mathrm{m} \mathrm{s}^{-1}\right)$ during the tow $\times$ duration of the tow $(\mathrm{s})$, and $\mathrm{A}=$ net mouth effective area $\left(9 \mathrm{~m}^{2}\right)$.

For each species, the mean and standard deviation of all body dimensions were estimated by stage [59]. Only for P. argus, which was by far the dominant species (see Section 3) with multiple larvae of each stage in both seasons, the mean BL of each mid- and late-stage was compared between seasons with a non-parametric Mann-Whitney test.

To characterize the biodiversity of phyllosomata along our study area, we estimated five ecological indices for each sampling station during each cruise: species richness $(S)$ and abundance $(N)$, as well as Shannon-Wiener's diversity $\left(H^{\prime}\right)$, Pielou's evenness $\left(J^{\prime}\right)$, and Simpson's dominance $(\lambda)$. The latter three combine measures of richness and abundance, hence providing greater ability to discriminate samples than $S$ or $N$ alone [58]. Each ecological index was compared between seasons (cruises) with a Student's $t$ test after checking for normality and homogeneity of variances.

The potential effect of season (cruise) on the assemblage composition of phyllosomata was examined using multivariate analyses. For these analyses, we considered as separate groups the mid- and late-stage phyllosomata of each species based on differences in age, vertical movement range, diet, and trophic position with increasing size [60-63]. Results were visualized with a non-metric multidimensional scaling (NMDS) ordination on the square-root transformed abundance data using the Bray-Curtis similarity measure [64]. The significance of the observed differences was further tested with a one-way analysis of similarity (ANOSIM). This test provides an R-value indicative of the degree of difference between samples. $R$-values close to 0 are indicative of little difference, while values close to 1 are indicative of a large difference in sample composition [65]. We then did a similarity percentage analysis (SIMPER, [64]) to identify those groups of phyllosomata responsible for the observed similarities between seasons. The software PRIMER 6 v6.1.9 [66] and PAST v4.05 [67] were used for these analyses.

\section{Results}

\subsection{Surface Geostrophic Current Fields}

The conditions of the altimetry-derived current fields remained fairly constant throughout each cruise; therefore, we chose the central date of each cruise to visualize the current field during that cruise. During the autumn cruise, an anticyclonic eddy was located south of Cuba and the velocity of the geostrophic currents off the Yucatan Peninsula increased northwards (Figure 2a). During the spring cruise, there was a large anticyclonic/cyclonic eddy system also south of Cuba and to the east of our study area (Figure 2b). In this cruise, differences in the sea surface height were greater than during the autumn cruise, resulting in stronger geostrophic currents. During both cruises, the geostrophic calculations from the CTD survey revealed the presence of a coastal counter-current and a submesoscale eddy south of Cozumel [48], but these features were close to the coast where altimetry measurements are not reliable. Therefore, they were not registered on the altimetry-deduced flow field. However, it is important to mention their existence because of their potential influence on temporal larval retention [48].

\subsection{Species Abundance and Stage Composition}

In total, we collected 2599 phyllosomata of both Achelata families, of which 2563 $(98.6 \%)$ were identified to species. The 36 remaining larvae (1.4\%) were too damaged to be identified with certainty. 
(a) Autumn 2012

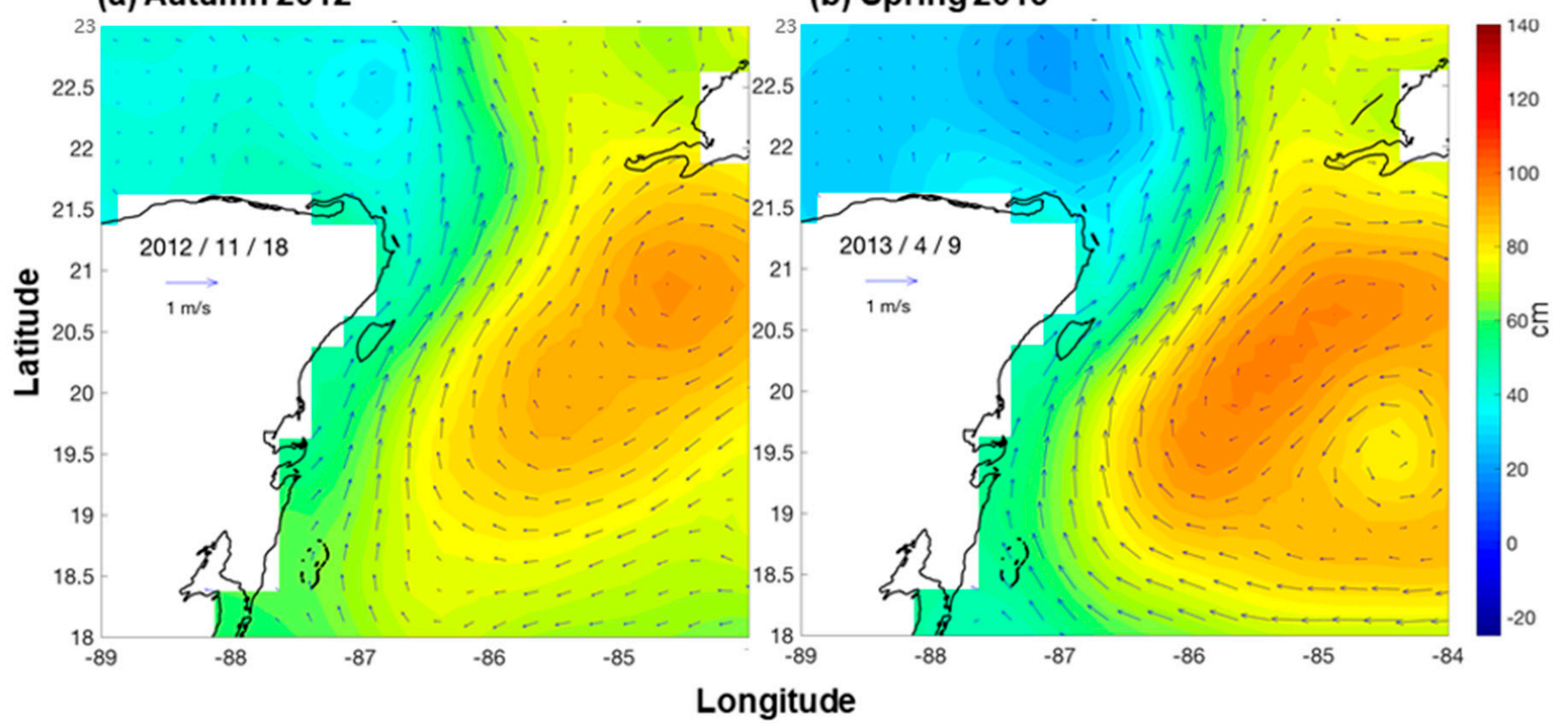

Figure 2. Surface geostrophic current field as derived from satellite-obtained sea surface dynamic altimetry data obtained from the Archiving, Validation, and Interpretation of Satellite Oceanographic data (AVISO) for (a) 18 November 2012 and (b) 9 April 2013.

In the autumn cruise, 53 of the 55 sampled stations (96.4\%) yielded 1742 phyllosomata, $1715(98.5 \%)$ of which were identified to species. Five species of Palinuridae accounted for $94.1 \%$ of these larvae, and three species of Scyllaridae for the remaining $4.9 \%$. The most abundant species was Panulirus argus (61.2\% of all the larvae), followed by P. guttatus (29\%), Parribacus antarcticus (3\%), Palinurellus gundlachi (2.7\%), Justitia longimana (2.2\%), Scyllarides aequinoctialis (1.9\%), Panulirus laevicauda and Scyllarus chacei (0.9\% of all the autumn larvae each) (Figure 2).

In the spring cruise, 29 of the 34 sampled stations (85.3\%) yielded 857 phyllosomata, of which $848(99 \%)$ were identified to species. Palinurids accounted for $93.6 \%$ of all the spring larvae, distributed in the five species; the rest $(6.4 \%)$ corresponded to two scyllarid species. Again, the most abundant species by far was P. argus (78.0\% of all the larvae), followed at a distance by P. guttatus (8.1\%), P. gundlachi (7.2\%), Scyllarus chacei $(3.8 \%)$, Scyllarides aequinoctialis $(2.6 \%)$, P. laevicauda (0.2\%), and J. longimana (0.1\%) (Figure 3$)$.

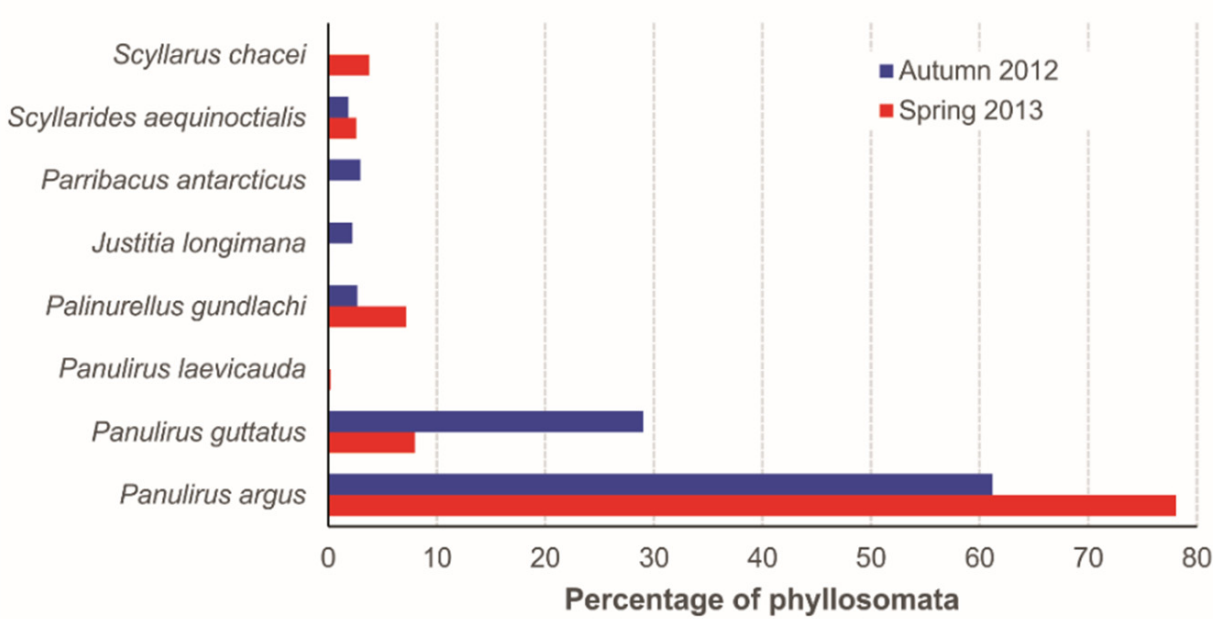

Figure 3. Percentage of phyllosomata (all stages) per species collected in the autumn 2012 cruise $(\mathrm{N}=1715)$ and the spring 2013 cruise $(\mathrm{N}=849)$. 
As expected, the vast majority of phyllosomata were mid- and late stages (Table 2), although a few early-stage larvae of $P$. gundlachi, P. antarcticus, and S. aequinoctialis were collected in either or both cruises (Table 2). In P. argus, P. guttatus, S. aequinoctialis, and J. longimana, mid-stage larvae outnumbered late-stage larvae in both cruises. This was also the case for $P$. antarcticus in the autumn cruise, the only one in which this species occurred (Table 2). Only one final phyllosoma of S. chacei (stage VII) and one final phyllosoma of $P$. laevicauda (stage XI) were collected in the autumn cruise. In the spring cruise, late-stage larvae outnumbered mid-stage larvae for P. gundlachi, whereas all the S. chacei larvae were late-stage phyllosomata. In this cruise, two phyllosomata X of P. laevicauda and one phyllosoma V of J. longimana were collected (Table 2).

Table 2. Number of phyllosomata of each species categorized into early-stage, mid-stage, and late-stage larvae by cruise ( $\mathrm{N}=$ total number of larvae).

\begin{tabular}{ccccccccc}
\hline \multirow{2}{*}{ Species } & \multicolumn{4}{c}{ Autumn $\mathbf{2 0 1 2}$} & \multicolumn{5}{c}{ Spring 2013 } \\
\cline { 2 - 9 } & $\mathbf{N}$ & Early & Mid & Late & N & Early & Mid & Late \\
\hline Panulirus argus & 1049 & 0 & 763 & 286 & 662 & 0 & 476 & 153 \\
Panulirus guttatus & 497 & 0 & 392 & 105 & 68 & 0 & 56 & 11 \\
Panulirus laevicauda & 1 & 0 & 0 & 1 & 2 & 0 & 0 & 2 \\
Palinurellus gundlachi & 46 & 1 & 9 & 36 & 61 & 14 & 12 & 35 \\
Justitia longimana & 38 & 0 & 25 & 13 & 1 & 0 & 1 & 0 \\
Parribacus antarcticus & 51 & 1 & 46 & 4 & 0 & 0 & 0 & 0 \\
Scyllarides & 32 & 1 & 23 & 8 & 22 & 1 & 20 & 1 \\
aequinoctialis & 1 & 0 & 0 & 1 & 32 & 0 & 0 & 32 \\
Scyllarus chacei & 1 & & & & & & &
\end{tabular}

The mean and standard deviation of each measurement by stage are provided for all the palinurids (Table 3) and scyllarids (Table 4) collected. Within the palinurids, the species with the largest larvae by stage were P. guttatus and J. longimana, and with the smallest larvae by stage P. gundlachi (Table 3). Within the scyllarids, the largest larvae by stage were those of $S$. aequinoctialis, and the smallest, by far, those of $S$. chacei (Table 4 ). In $P$. argus, significant differences in size between the seasons occurred in stages $\mathrm{V}(U=99$, $\left.n_{1}=38, n_{2}=16, p<0.001\right)$, VII $\left(U=19,594, n_{1}=233, n_{2}=191, p=0.034\right)$, VIII $(U=6997$, $\left.n_{1}=214, n_{2}=15, p<0.001\right)$, and $X\left(U=263, n_{1}=46, n_{2}=18, p=0.024\right)$ but not in stages VI $\left(U=18,992, n_{1}=241, n_{2}=162, p=0.645\right)$ or IX $\left(U=4679, n_{1}=136, n_{2}=73, p=0.495\right)$.

Table 3. Number of mid- and late stage palinurid phyllosomata by species and stage (N), and morphometric measurements: BL (total body length), CL (cephalic length), CW (cephalic width). All measurements in $\mathrm{mm}$. SD: standard deviation.

\begin{tabular}{cccccc}
\hline Species and Stage & $\mathbf{N}$ & $\begin{array}{c}\text { BL } \\
\text { (Range) }\end{array}$ & $\begin{array}{c}\text { BL } \\
\text { (Mean } \pm \text { SD) }\end{array}$ & $\begin{array}{c}\text { CL } \\
\text { (Mean } \pm \text { SD) }\end{array}$ & $\begin{array}{c}\text { CW } \\
\text { (Mean } \pm \text { SD) }\end{array}$ \\
\hline $\begin{array}{c}\text { Panulirus argus } \\
\text { Stage V }\end{array}$ & 54 & $4.3-8.1$ & $6.0 \pm 0.9$ & $4.3 \pm 0.8$ & $2.3 \pm 0.4$ \\
Stage VI & 403 & $5.7-12.8$ & $9.3 \pm 1.4$ & $6.8 \pm 1.1$ & $3.7 \pm 0.6$ \\
Stage VII & 424 & $9.2-17.0$ & $13.3 \pm 1.4$ & $9.6 \pm 1.1$ & $5.4 \pm 0.6$ \\
Stage VIII & 319 & $13.4-22.6$ & $18.4 \pm 1.8$ & $12.4 \pm 1.2$ & $7.2 \pm 0.7$ \\
Stage IX & 209 & $18.0-23.0$ & $20.1 \pm 0.9$ & $13.3 \pm 1.1$ & $7.8 \pm 0.6$ \\
Stage X & 64 & $22.0-30.0$ & $25.0 \pm 1.3$ & $15.1 \pm 1.1$ & $8.5 \pm 0.7$ \\
\hline
\end{tabular}


Table 3. Cont.

\begin{tabular}{|c|c|c|c|c|c|}
\hline Species and Stage & $\mathbf{N}$ & $\begin{array}{c}\text { BL } \\
\text { (Range) }\end{array}$ & $\begin{array}{c}\text { BL } \\
(\text { Mean } \pm \text { SD) }\end{array}$ & $\begin{array}{c}\text { CL } \\
(\text { Mean } \pm \text { SD) }\end{array}$ & $\begin{array}{c}\mathrm{CW} \\
(\text { Mean } \pm \mathrm{SD})\end{array}$ \\
\hline \multicolumn{6}{|l|}{ Panulirus guttatus } \\
\hline Stage V & 28 & $6.9-11.0$ & $9.2 \pm 1.1$ & $6.7 \pm 0.8$ & $3.6 \pm 0.6$ \\
\hline Stage VI & 234 & $10.0-16.4$ & $12.6 \pm 1.4$ & $9.4 \pm 1.4$ & $5.3 \pm 0.8$ \\
\hline Stage VII & 123 & $11.5-21.0$ & $16.7 \pm 1.9$ & $12.5 \pm 1.8$ & $7.3 \pm 1.4$ \\
\hline Stage VIII & 64 & $14.5-28.5$ & $21.7 \pm 2.1$ & $16.0 \pm 1.5$ & $9.6 \pm 1.2$ \\
\hline Stage IX & 43 & $19.5-32.1$ & $26.9 \pm 2.7$ & $19.1 \pm 1.9$ & $11.6 \pm 1.6$ \\
\hline Stage $X$ & 10 & $28.0-33.0$ & $30.6 \pm 1.4$ & $21.0 \pm 1.0$ & $13.0 \pm 0.5$ \\
\hline Stage XI & 4 & $37.5-42.5$ & $39.8 \pm 2.1$ & $24.8 \pm 0.9$ & $14.9 \pm 0.8$ \\
\hline \multicolumn{6}{|l|}{ Palinurellus gundlachi } \\
\hline Stage V & 11 & $5.0-6.5$ & $5.9 \pm 0.6$ & $3.7 \pm 0.9$ & $3.8 \pm 1.0$ \\
\hline Stage VI & 5 & $6.3-7.0$ & $6.7 \pm 0.3$ & $5.0 \pm 0.4$ & $4.4 \pm 0.4$ \\
\hline Stage VII & 3 & $7.4-8.5$ & $8.0 \pm 0.6$ & $5.3 \pm 0.6$ & $5.8 \pm 0.2$ \\
\hline Stage VIII & 9 & $8.5-11.2$ & $9.6 \pm 0.8$ & $7.0 \pm 0.7$ & $6.3 \pm 1.2$ \\
\hline Stage IX & 8 & $9.0-10.7$ & $10.0 \pm 0.6$ & $6.6 \pm 1.2$ & $6.8 \pm 0.4$ \\
\hline Stage $X$ & 18 & $11.0-13.5$ & $11.7 \pm 0.7$ & $8.0 \pm 0.7$ & $8.1 \pm 1.2$ \\
\hline Stage XI & 14 & $11.3-16.0$ & $13.0 \pm 1.6$ & $8.9 \pm 1.1$ & $8.3 \pm 0.8$ \\
\hline Stage XII & 33 & $12.2-22.0$ & $15.7 \pm 1.1$ & $10.4 \pm 1.2$ & $9.4 \pm 0.7$ \\
\hline \multicolumn{6}{|l|}{ Justitia longimana } \\
\hline Stage V & 4 & $8.0-10.0$ & $8.8 \pm 0.9$ & $6.8 \pm 0.6$ & $4.1 \pm 0.6$ \\
\hline Stage VI & 8 & $11.3-16.1$ & $13.5 \pm 1.6$ & $10.6 \pm 1.2$ & $7.0 \pm 1.2$ \\
\hline Stage VII & 5 & $17.0-20.0$ & $18.1 \pm 1.2$ & $13.9 \pm 1.0$ & $10.1 \pm 1.4$ \\
\hline Stage VIII & 6 & $20.0-23.8$ & $21.0 \pm 1.4$ & $14.8 \pm 2.3$ & $11.8 \pm 0.7$ \\
\hline Stage IX & 12 & $24.0-28.0$ & $26.0 \pm 1.3$ & $18.3 \pm 1.0$ & $14.4 \pm 0.8$ \\
\hline Stage $X$ & 1 & & 35.5 & 22.6 & 16.6 \\
\hline \multicolumn{6}{|l|}{ Panulirus laevicauda } \\
\hline Stage IX & 1 & & 14.8 & 11.5 & 7.0 \\
\hline Stage $X$ & 1 & & 16.5 & 12.5 & 8.0 \\
\hline Stage XI & 1 & & 22.5 & 17.0 & 10.5 \\
\hline
\end{tabular}

Table 4. Number of mid- and late stage scyllarid phyllosomata by species and stage (N), and morphometric measurements: BL (total body length), CL (cephalic length), CW (cephalic width). All measurements in $\mathrm{mm}$. SD: standard deviation.

\begin{tabular}{cccccc}
\hline Species and Stage & $\mathbf{N}$ & $\begin{array}{c}\text { BL } \\
\text { (Range) }\end{array}$ & $\begin{array}{c}\text { BL } \\
\text { (mean } \pm \text { SD) }\end{array}$ & $\begin{array}{c}\text { CL } \\
\text { (mean } \pm \text { SD) }\end{array}$ & $\begin{array}{c}\text { CW } \\
\text { (mean } \pm \text { SD) }\end{array}$ \\
\hline Parribacus antarcticus & & & & & \\
Stage V & 1 & & 6.0 & 4.8 & 2.7 \\
Stage VI & 24 & $8.5-15.0$ & $11.0 \pm 1.7$ & $8.9 \pm 1.6$ & $5.8 \pm 1.1$ \\
Stage VII & 12 & $13.0-17.5$ & $15.3 \pm 1.3$ & $12.5 \pm 1.0$ & $9.3 \pm 3.2$ \\
Stage VIII & 9 & $18.8-28.3$ & $21.3 \pm 2.8$ & $17.4 \pm 2.1$ & $13.0 \pm 3.0$ \\
Stage IX & 2 & $22.9-25.1$ & $24.0 \pm 1.6$ & $20.0 \pm 1.3$ & $14.9 \pm 1.2$ \\
Stage X & 2 & $33.0-36.1$ & $34.6 \pm 2.2$ & $28.3 \pm 1.8$ & $22.3 \pm 1.5$ \\
\hline Scyllarides aequinoctialis & & & & & \\
Stage IV & 2 & $4.0-4.4$ & $4.2 \pm 0.3$ & $3.4 \pm 0.6$ & $1.9 \pm 0.2$ \\
Stage VI & 7 & $6.3-9.8$ & $7.8 \pm 1.1$ & $6.0 \pm 1.1$ & $3.8 \pm 0.7$ \\
Stage VII & 9 & $7.3-10.3$ & $9.3 \pm 0.8$ & $7.7 \pm 1.8$ & $4.5 \pm 0.6$ \\
Stage VIII & 13 & $10.3-18.4$ & $14.4 \pm 2.5$ & $11.1 \pm 2.0$ & $7.6 \pm 1.6$ \\
Stage IX & 13 & $18.0-26.0$ & $23.3 \pm 2.7$ & $18.6 \pm 2.0$ & $14.0 \pm 2.1$ \\
Stage X & 7 & $27.0-33.0$ & $29.8 \pm 2.3$ & $22.2 \pm 1.5$ & $17.1 \pm 1.3$ \\
Stage XI & 2 & $38.6-41.2$ & $39.9 \pm 1.8$ & $27.4 \pm 1.5$ & $20.1 \pm 0.8$ \\
Stage XII & 1 & & 42.0 & 28.0 & 22.0 \\
\hline Scyllarus chacei & & & & & \\
Stage VI & 2 & $5.0-7.3$ & $6.2 \pm 1.6$ & $4.2 \pm 1.1$ & $4.7 \pm 0.7$ \\
Stage VII & 31 & $9.2-11.4$ & $10.5 \pm 0.5$ & $5.9 \pm 0.5$ & $7.1 \pm 1.3$ \\
\hline
\end{tabular}




\subsection{Phyllosomata Density and Spatial Distribution}

The densities of the mid- to late-stage phyllosomata (all the species combined) were low across the study area. The values per sampling station ranged from 0 to 4.1 ind $1000 \mathrm{~m}^{-3}$ in the autumn 2012 cruise (Figure 4a), and from 0 to 9.7 ind $1000 \mathrm{~m}^{-3}$ in the spring 2013 cruise (Figure 4b). In general, greater densities of phyllosomata occurred south of Cozumel Island in the autumn cruise and north of Cozumel in the spring.
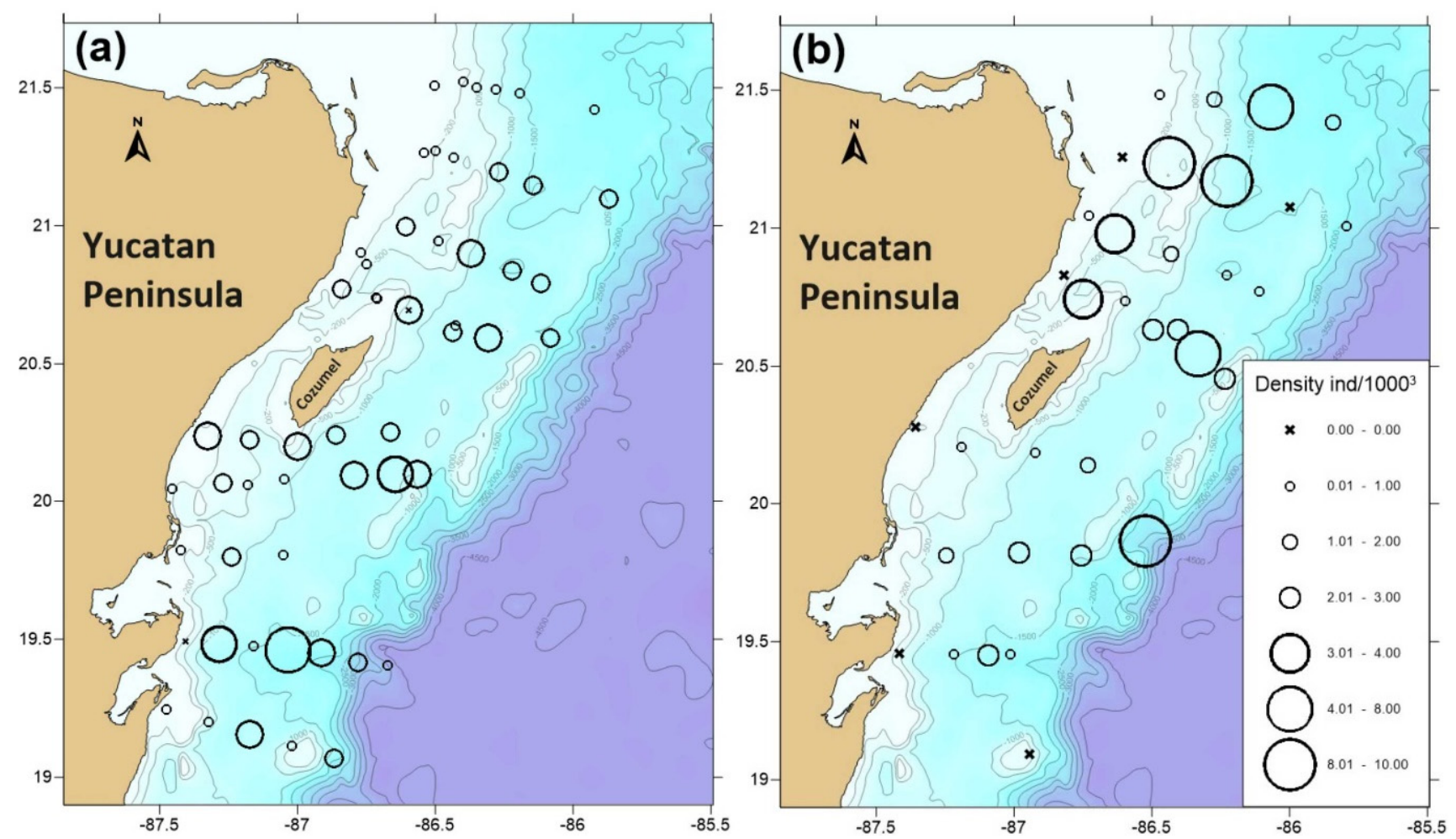

Figure 4. Density (number of larvae per $1000 \mathrm{~m}^{3}$ of water) of phyllosomata (all species and stages combined) by sampling station. (a) autumn cruise; (b) spring cruise. The scale is the same for both panels.

The most frequent larvae were the mid- and late-stage phyllosomata of $P$. argus, occurring in $89 \%$ and $87 \%$ of the 55 sampling stations in autumn, respectively, and in $70 \%$ and $61 \%$ of the 34 stations in spring, respectively. In general, the densities of the mid-stage larvae were lower in the autumn (range: 0-2.6 ind $1000 \mathrm{~m}^{-3}$ ), with greater concentrations south of Cozumel (Figure 5a), than in the spring (range 0.1-7.0 ind $1000 \mathrm{~m}^{-3}$ ), when higher values mostly occurred close to the Yucatan Channel (Figure $5 b$ ). The densities of the late stages of P. argus were even lower (0.1-1.2 ind $1000 \mathrm{~m}^{-3}$ in autumn and 0.1-2.7 ind $1000 \mathrm{~m}^{-3}$ in the spring), with the highest values recorded in two stations in the southern zone, very close to the coast, in the autumn cruise (Figure 5c) and in one southern station far from the coast and another station close to the Yucatan Channel in the spring cruise (Figure 5d).

The mid-stage phyllosomata of P. guttatus occurred in $80 \%$ of the autumn cruise stations and $51.5 \%$ of the spring cruise stations. The maximum densities were 1.02 and 0.91 ind $1000 \mathrm{~m}^{-3}$, respectively, but there were more stations with $0.5-1$ ind $1000 \mathrm{~m}^{-3}$ in the autumn cruise (Figure 6a,c). The late stages of P. guttatus were collected in $63.3 \%$ of the autumn cruise stations but in only $27.3 \%$ of the spring cruise stations. The maximum densities were 0.38 and 0.15 ind $1000 \mathrm{~m}^{-3}$, respectively. Therefore, densities $>0.2$ ind $1000 \mathrm{~m}^{-3}$ occurred only in seven stations of the autumn cruise, distributed throughout the study area (Figure $6 \mathrm{~b}, \mathrm{~d}$ ). 

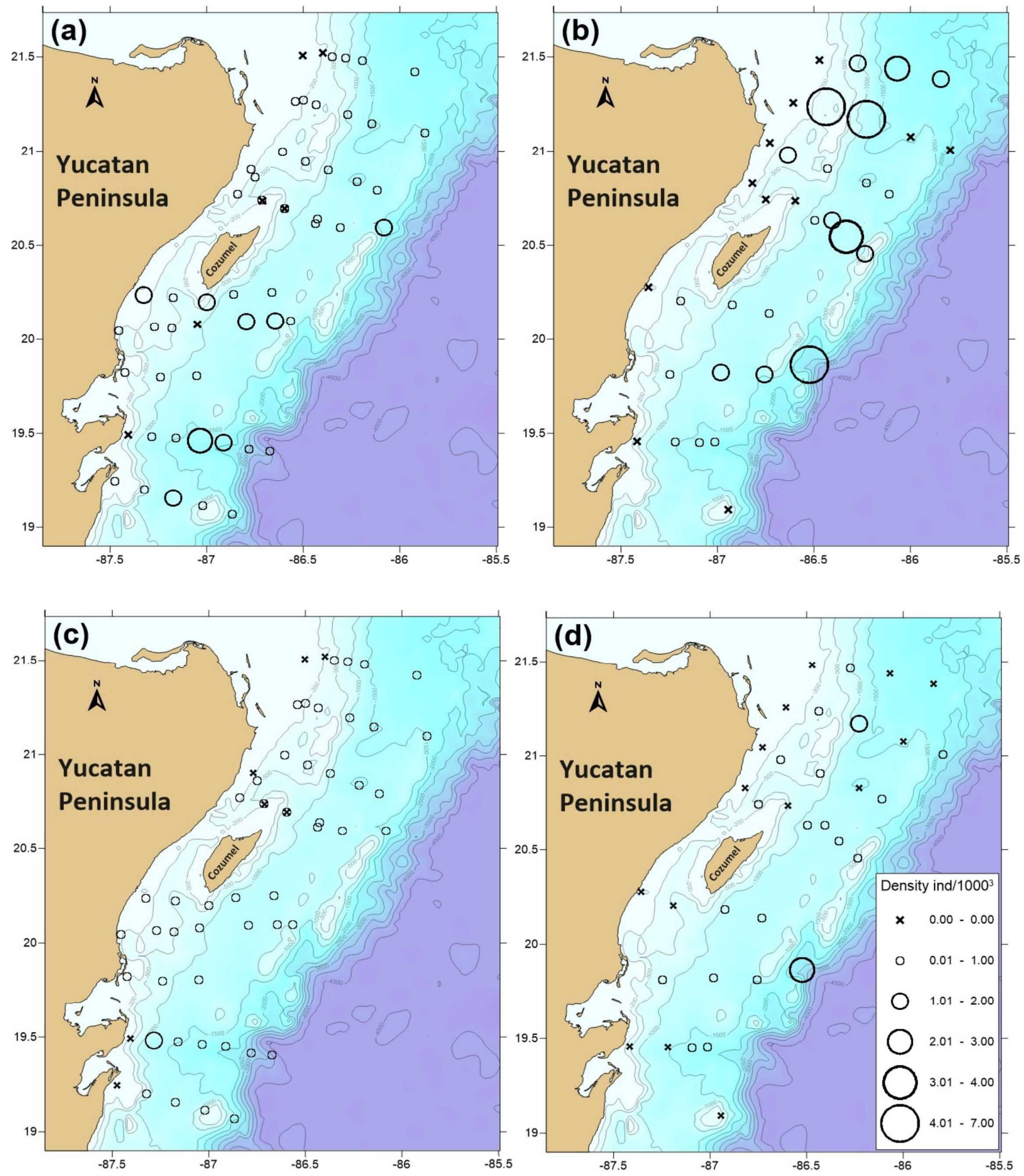

Figure 5. Density (number of larvae per $1000 \mathrm{~m}^{3}$ of water) of phyllosomata of Panulirus argus by sampling station. (a) midstage phyllosomata, autumn cruise; (b) mid-stage phyllosomata, spring cruise; (c) late-stage phyllosomata, autumn cruise; (d) late-stage phyllosomata, spring cruise. The scale is the same for all panels. 

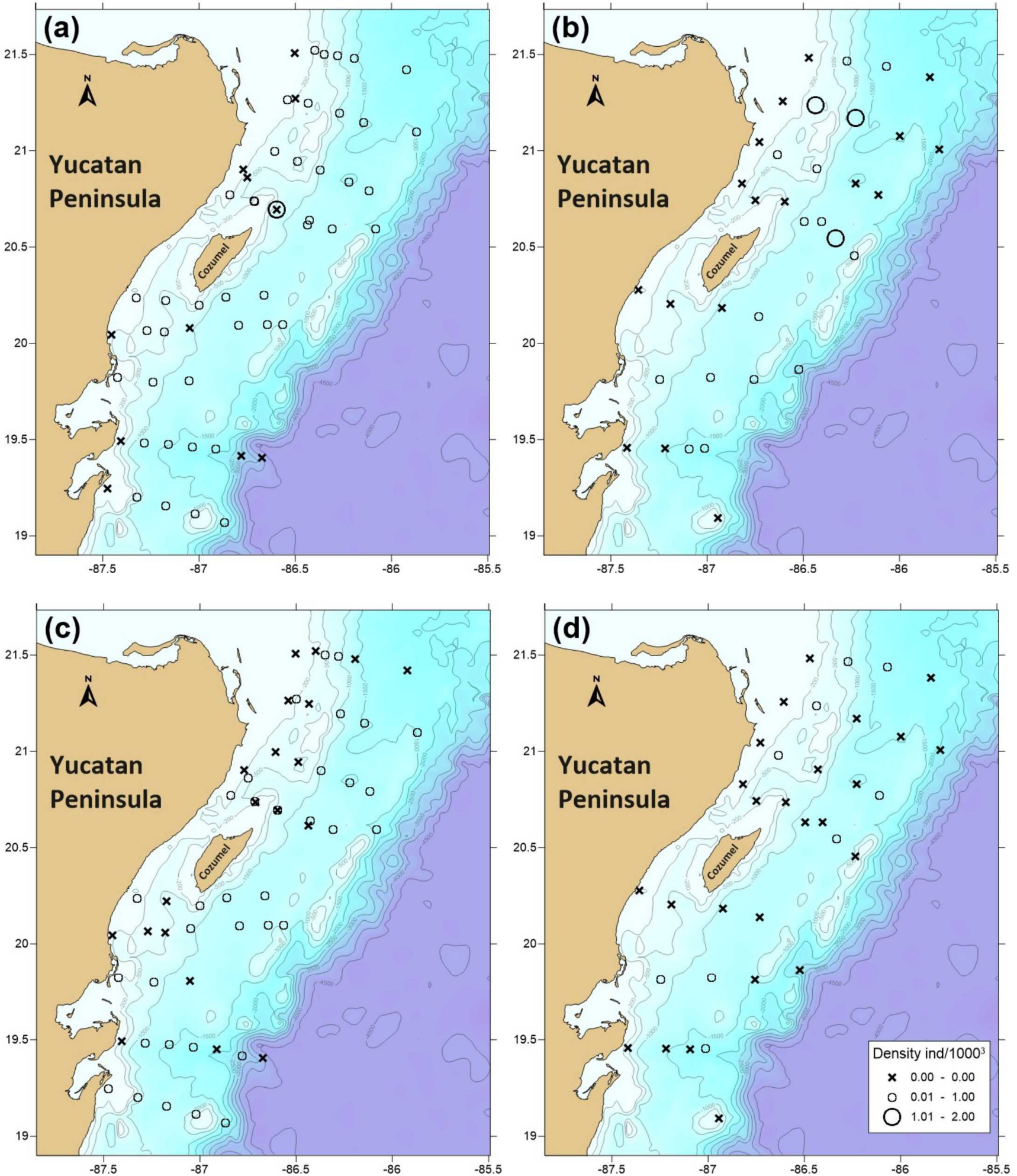

Figure 6. Density (number of larvae per $1000 \mathrm{~m}^{3}$ ) of water of phyllosomata of Panulirus guttatus by sampling station. (a) mid-stage phyllosomata, autumn cruise; (b) mid-stage phyllosomata, spring cruise; (c) late-stage phyllosomata, autumn cruise; (d) late-stage phyllosomata, spring cruise. The scale is the same for all panels.

Palinurellus gundlachi was the third most frequent species. In the autumn cruise, the mid- and late-stage phyllosomata of P. gundlachi appeared in $80 \%$ and $34.5 \%$ of the stations, respectively, with densities similar to those of P. guttatus (Figure 7a,b). The maximum values were 1.02 and 0.36 ind $1000 \mathrm{~m}^{-3}$, respectively. In the spring cruise, the mid- and late- 
stage larvae occurred in $23.5 \%$ and $38.2 \%$ of the stations, respectively, with higher densities for late stages $\left(1.18\right.$ ind $\left.1000 \mathrm{~m}^{-3}\right)$ than for mid-stages $\left(0.47\right.$ ind $\left.1000 \mathrm{~m}^{-3}\right)$ (Figure $7 \mathrm{c}, \mathrm{d}$ ). In the spring cruise as well, early stages appeared in $25.5 \%$ of the stations but at rather low densities (maximum 0.3 ind $1000 \mathrm{~m}^{-3}$ ) (not shown). In the case of S. aequinoctialis, the mid-stage larvae occurred in $21.8 \%$ of the autumn stations at maximum densities of 0.23 ind $1000 \mathrm{~m}^{-3}$, and in $30.3 \%$ of the spring stations at densities of up to $0.47 \mathrm{ind} 1000 \mathrm{~m}^{-3}$ (Figure $8 \mathrm{a}, \mathrm{b}$ ). In contrast, the late stages were present only in the autumn (in $12.7 \%$ of the stations) at a maximum density of 0.1 ind $1000 \mathrm{~m}^{-3}$ (Figure $8 \mathrm{c}$ ). The late stages of $S$. chacei only occurred in the spring cruise, appearing in $39.4 \%$ of the sampled stations at densities of up to 2.12 ind $1000 \mathrm{~m}^{-3}$ (Figure $8 \mathrm{~d}$ ).

Two species, J. longimana and P. antarcticus, virtually only occurred in the autumn cruise. The mid- and late-stage larvae of J. longimana occurred in 36.7 and $18.2 \%$ of the stations at maximum densities of 0.15 and 0.22 ind $1000 \mathrm{~m}^{-3}$, respectively (Figure $9 \mathrm{a}, \mathrm{b}$ ). As for P. antarcticus, the mid- and late-stage larvae occurred in $34.5 \%$ and only $7.3 \%$ of the sampling stations, respectively, at maximum densities of 0.19 and 0.07 ind $1000 \mathrm{~m}^{-3}$, respectively (Figure 10a,b).

\subsection{Phyllosomata Biodiversity and Assemblage Composition}

The biodiversity and assemblage composition analysis of the phyllosomata included 14 groups: the mid- and late-stage phyllosomata of P. argus, P. guttatus, P. gundlachi, J. longimana, P. antarcticus, and S. aequinoctialis, and the late-stage larvae of $S$. chacei and P. laevicauda. In all of the ecological indices, the variances between the cruises were homogeneous (Levene's tests, all of the $p^{\prime}$ s $>1.0$ ) and the data were normally distributed (Shapiro-Wilk tests, all of the $\left.p^{\prime} s>0.1\right)$. Therefore, $t$-tests were used to compare all of the indices between the cruises (Table 5). Neither $S$ nor $N$ varied with the cruise. Prior to estimating the three compound indices, we removed the data from six sampling stations in the autumn cruise and three in the spring cruise that yielded only one phyllosoma. All the compound indices differed significantly between the cruises. $H^{\prime}$ and $J^{\prime}$ were higher in the autumn, whereas $\lambda$ was higher in the spring (Table 5).

The NMDS 2D-plot showed great overlap in the assemblage composition of the phyllosomata from both cruises. This was confirmed by the results of an ANOSIM $(R=0.143)$. (Figure 11). A SIMPER (Appendix A) revealed that, within the autumn cruise, the assemblage composition exhibited an average similarity among the samples of $45.9 \%$, mainly due to the contribution of the mid-stage larvae of P. argus and P. guttatus $(36.1 \%$ and $24.6 \%$, respectively), followed by the late-stage larvae of the same species $(21.7 \%$ and $9.3 \%$, respectively). Within the spring cruise, the average similarity among the samples was $44.4 \%$, with the mid-stage larvae of $P$. argus emerging again as the main contributor $(51.7 \%)$, followed by the late-stage $P$. argus $(18.6 \%)$ and mid-stage $P$. guttatus $(9.4 \%)$. In the autumn cruise, only four larval groups accounted for $90 \%$ of the observed similarity, whereas, in the spring cruise, six groups accounted for this percentage. Between the seasons, the phyllosomata assemblage had a mean dissimilarity of $59.7 \%$, with eight groups accounting for nearly $90 \%$ of this dissimilarity. The mid- and late-stage larvae of P. argus were the main contributors to this dissimilarity between the cruises (25.3\% and $15.7 \%$, respectively), followed by the mid- and late-stage larvae of P. guttatus (15.6 and 8.6\%, respectively), and the late-stage larvae of S. chacei (7.8\%) and P. gundlachi (7.1\%) (Appendix A). 

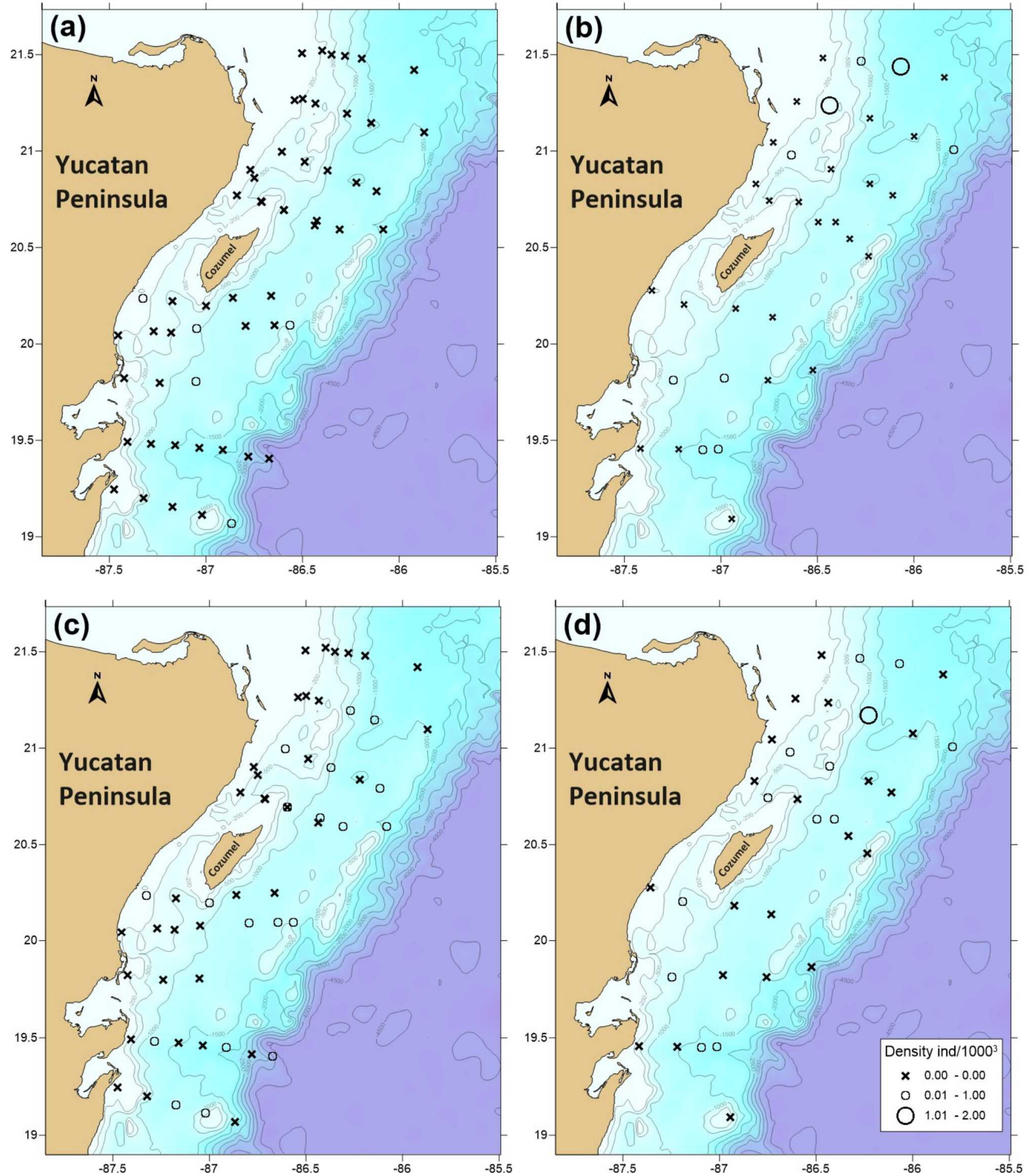

Figure 7. Density (number of larvae per $1000 \mathrm{~m}^{3}$ of water) of phyllosomata of Palinurellus gundlachi by sampling station. (a) mid-stage phyllosomata, autumn cruise; (b) mid-stage phyllosomata, spring cruise; (c) late-stage phyllosomata, autumn cruise; (d) late-stage phyllosomata, spring cruise. The scale is the same for all panels. 

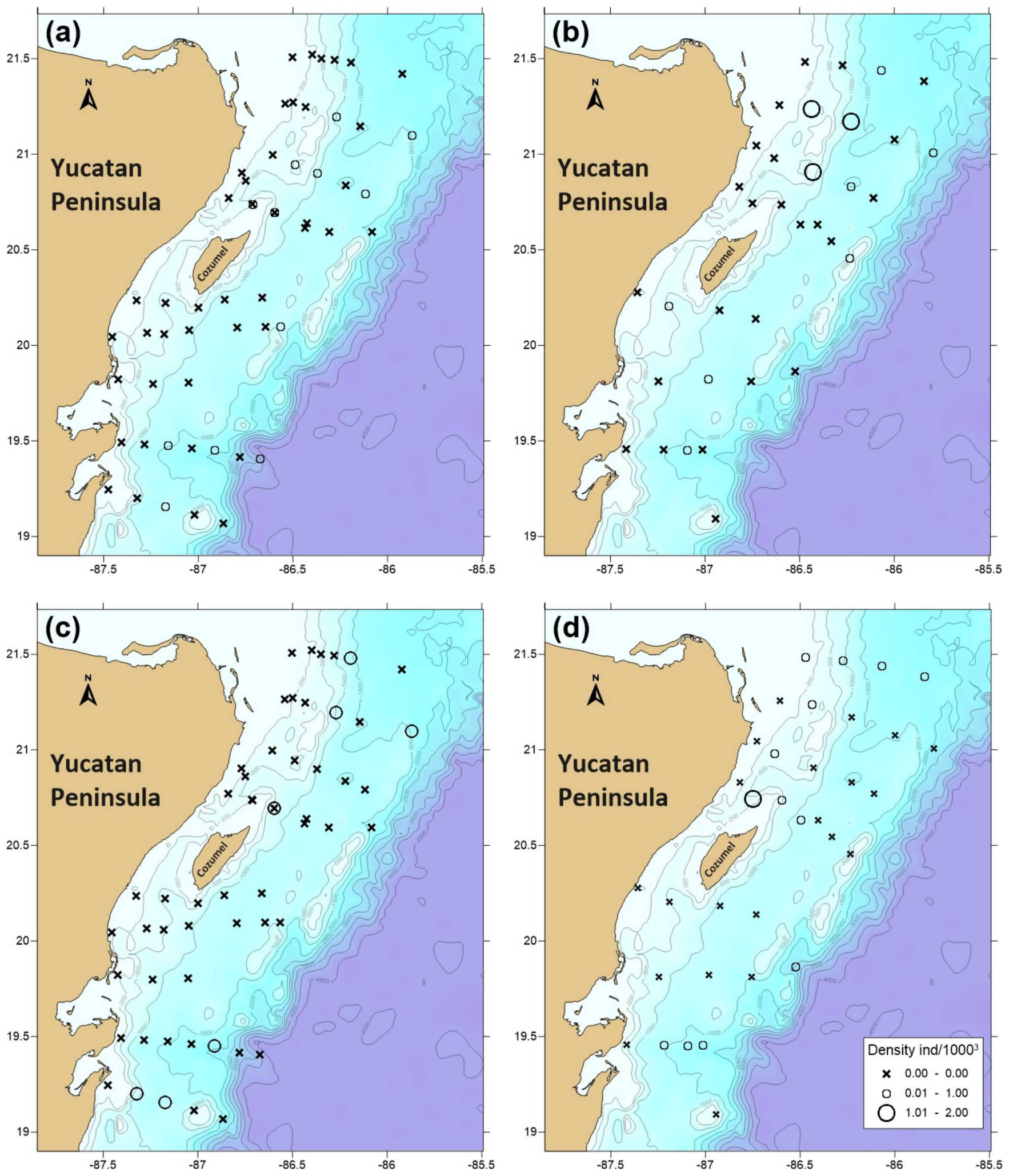

Figure 8. Density (number of larvae per $1000 \mathrm{~m}^{3}$ of water) of phyllosomata by sampling station. Scyllarides aequinoctialis: (a) mid-stage phyllosomata, autumn cruise; (b) mid-stage phyllosomata, spring cruise; (c) late-stage phyllosomata, autumn cruise. Scyllarus chacei: (d) late-stage phyllosomata, spring cruise. The scale is the same for all panels. 

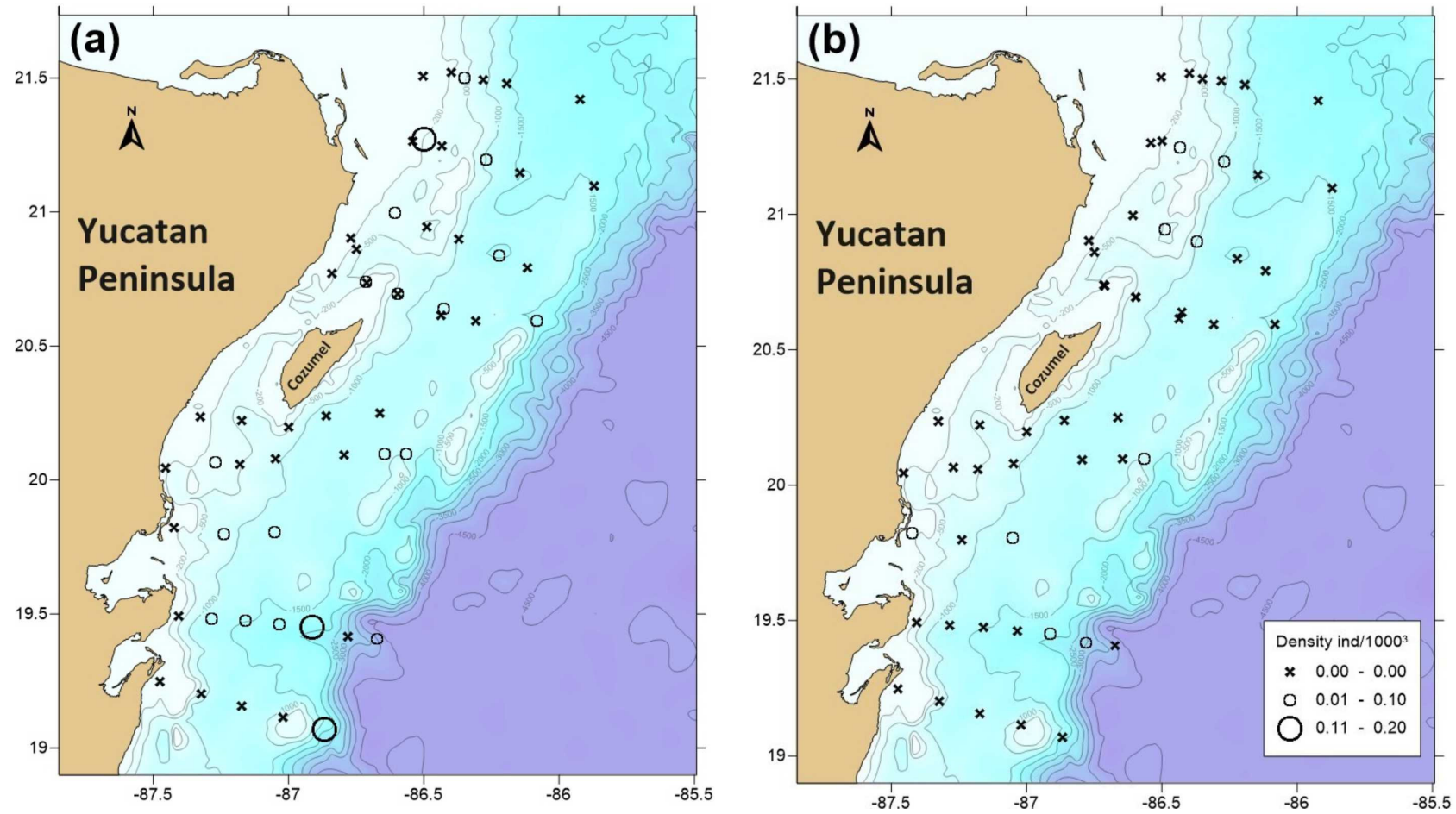

Figure 9. Density (number of larvae per $1000 \mathrm{~m}^{3}$ of water) of (a) mid-stage phyllosomata and (b) late-stage phyllosomata of Justitia longimana by sampling station during the autumn 2012 cruise. The scale is the same for both panels.
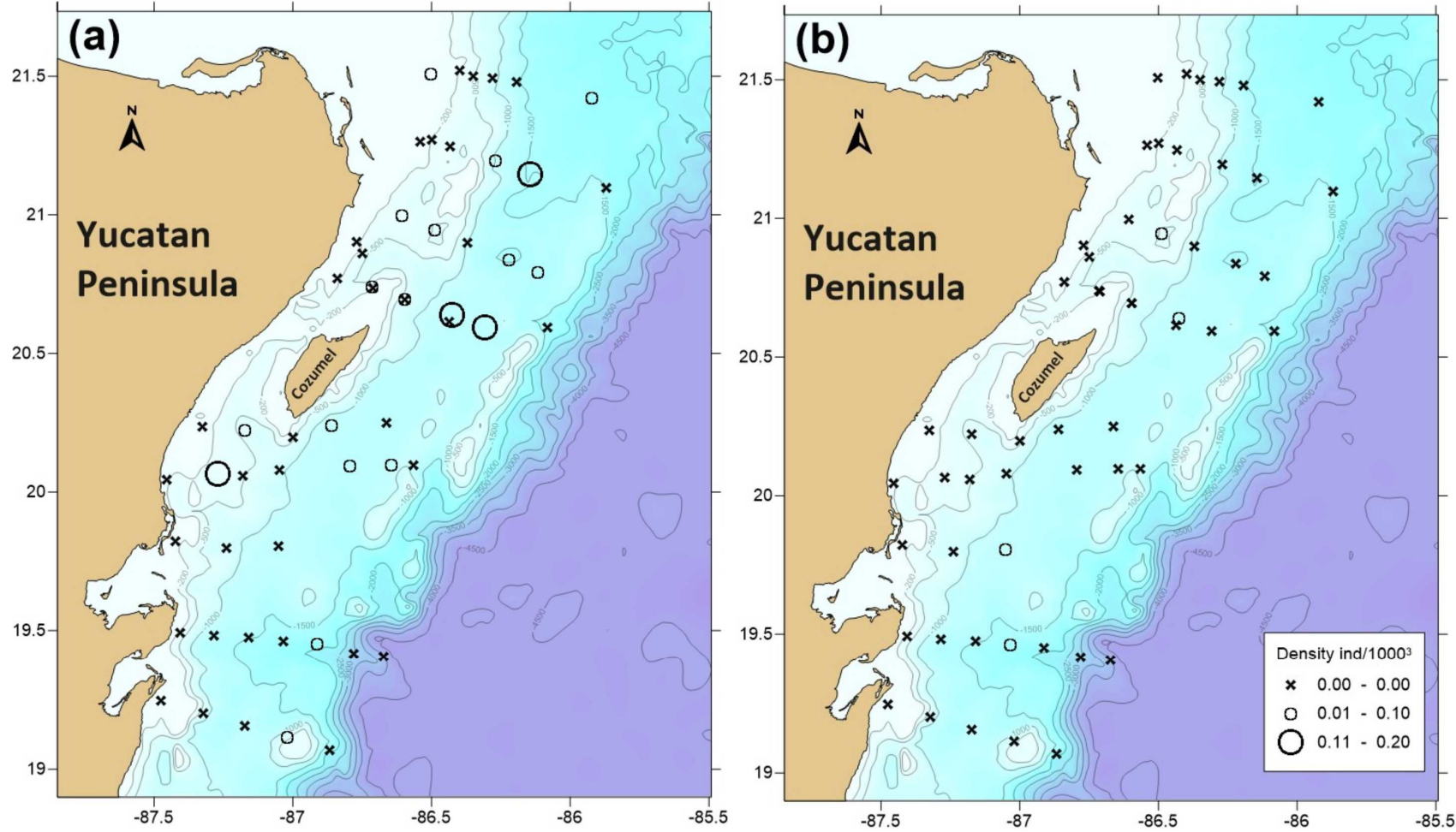

Figure 10. Density (number of larvae per $1000 \mathrm{~m}^{3}$ of water) of (a) mid-stage phyllosomata and (b) late-stage phyllosomata of Parribacus antarcticus by sampling station during the autumn 2012 cruise. The scale is the same for both panels. 
Table 5. Ecological indices for phyllosomata by cruise. Mean \pm standard deviation of species richness $(S)$, number of individuals $(N)$, Shannon-Wiener's diversity $\left(H^{\prime}\right)$, Pielou's evenness $\left(J^{\prime}\right)$, and Simpson's dominance $(\lambda)$, and results of Student's $t$-tests comparing each index between the autumn 2012 and the spring 2013 cruises.

\begin{tabular}{cccccc}
\hline Ecological Index & Autumn 2012 & Spring 2013 & df & $\boldsymbol{t}$ & $\boldsymbol{p}$ \\
\hline$S$ & $4.9 \pm 0.29$ & $4.3 \pm 0.38$ & 85 & 1.276 & 0.2056 \\
$N$ & $29.0 \pm 3.28$ & $28.5 \pm 4.97$ & 85 & 0.082 & 0.9348 \\
$H^{\prime}$ & $1.2396 \pm 0.0425$ & $1.0023 \pm 0.0625$ & 76 & 3.15 & 0.0050 \\
$J^{\prime}$ & $0.7380 \pm 0.0159$ & $0.6989 \pm 0.0258$ & 76 & 2.888 & 0.0023 \\
$\lambda$ & $0.3203 \pm 0.0163$ & $0.4472 \pm 0.0256$ & 76 & 4.303 & $<0.0001$ \\
\hline
\end{tabular}

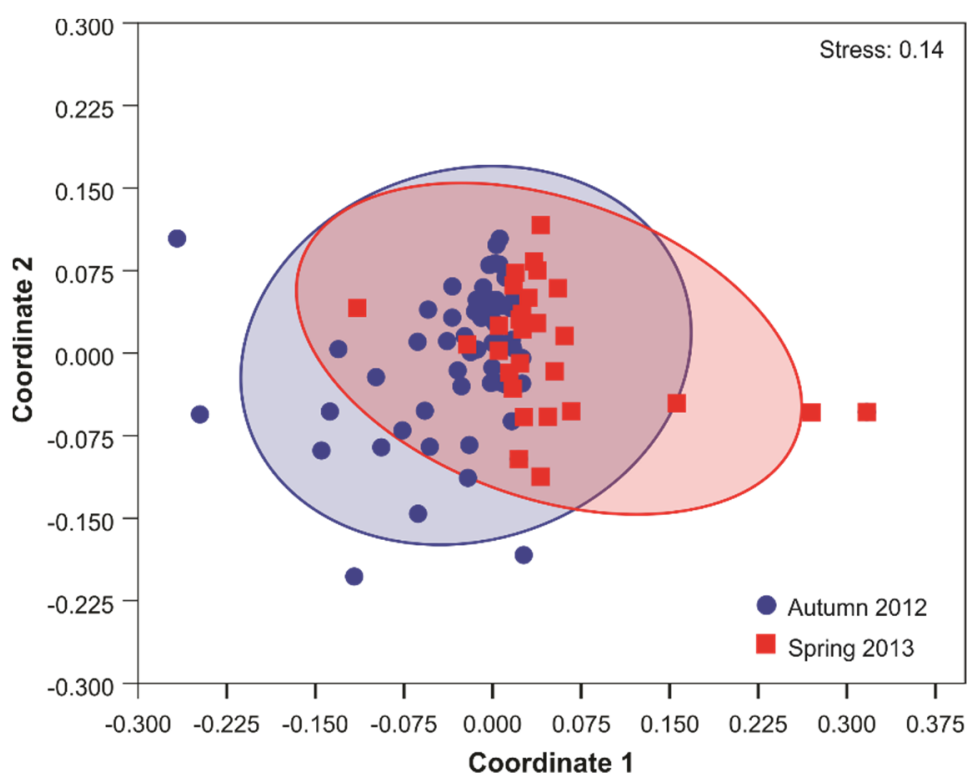

Figure 11. Non-metric multi-dimensional scaling ordinations (NMDS) for the phyllosomata assemblage structure in plankton samples obtained with the Tucker trawl in the autumn cruise (blue dots) and the spring cruise (red dots). The ordinations show the $95 \%$ concentration ellipses.

\section{Discussion}

This study is the first targeting the diversity and spatial distribution of mid- to latestage phyllosomata of Achelata in two different seasons (autumn 2012 and spring 2013) in the oceanic waters of the western Caribbean Sea. Our sampling scheme focused on relatively large larvae, using nets of large dimensions and mesh sizes towed at high velocities [48]. Moreover, by sampling exclusively during the night in the top $20 \mathrm{~m}$ of the water column, we were able to obtain large numbers of phyllosomata, which rise near the surface at night and descend deeper in the water column during the day $[27,28,52]$.

Of the 13 species of adult Achelata (five palinurids and eight scyllarids) present in the area, we obtained the phyllosomata of eight: all five palinurids (Panulirus argus, P. guttatus, P. laevicauda, Justitia longimana, Palinurellus gundlachi) but only three scyllarids (Scyllarides aequinoctialis, Parribacus antarcticus, Scyllarus chacei). Previous studies [37-41] had already reported on the phyllosomata of these species, alone or in different combinations, along the Mexican Caribbean, although those studies collected far more early- than mid-stage phyllosomata and very few late-stage larvae.

The density distributions of all the species confirm that mid- to late-stage phyllosomata, but particularly the latter, are highly diluted [68]. The mortality throughout the larval phase has been estimated at 97.3-99.6\% for several palinurid species (Panulirus interruptus: [69], Jasus lalandii: [70], J. edwardsii: [71]); therefore, the abundance of late-stage phyllosomata would be expected to be lower than that of early- and mid-stage phyllosomata $[68,72]$. 


\subsection{Palinurids}

In both our cruises, the palinurid larvae far outnumbered the scyllarid larvae, which is a common pattern in offshore oceanic waters (e.g., $[41,54,73])$. The overwhelming dominance of $P$. argus phyllosomata over those of all the other species is consistent with other studies throughout the wider Caribbean region [37,38,40,41,74,75]. Benthic populations of $P$. argus occupy many different habitats-from shallow reef lagoons to deep reefs and rocky habitats down to $\sim 70 \mathrm{~m}$ in depth [76] —and sustain important fisheries [24]. Although subtropical populations of $P$. argus exhibit seasonal reproduction [77], tropical populations reproduce year-round, with females spawning up to two to four times per year depending on their size [77-80]. These features of P. argus, in conjunction with a relatively short larval duration (for a palinurid) of 5-7 months [11], may explain the dominance of the phyllosomata of this species in both our cruises. In our study area, the recruitment of P. argus postlarvae to coastal habitats also occurs year-round [33], and the mean size of the postlarvae has been found to vary through time [48,81]. In our cruises, the mean size of P. argus phyllosomata varied with the season in some stages but not in other stages. These differences may be related to variations in the individual larval histories, including temperature regimes and variability in food availability throughout the larval development $[51,63,82]$.

The second most abundant species in our samples was P. guttatus, particularly in the autumn cruise. Canto-García et al. [41] reported P. guttatus as the second most abundant species in their winter cruise but as the third most abundant in their spring cruise. These authors used DNA barcoding to discern between the early stages of P. argus and P. guttatus, which are morphologically very similar $[15,41]$. However, the size and morphological differences between P. argus and P. guttatus become more evident in the more advanced stages. Baisre and Alfonso [17] described phyllosomata VI to X (which they considered the subfinal stage) of $P$. guttatus from plankton samples. We found several final phyllosomata of P. guttatus (i.e., with bilobed gill buds in pereopods 1 to 4 ) and assigned them to stage XI following Baisre and Alfonso [17]. More recently, Goldstein et al. [18] successfully reared larvae of P. guttatus up to stage IX (which they considered the subfinal stage), but this paper was not available when our study was conducted.

Numerous individuals of all the mid- and late stages of P. guttatus were obtained in our autumn cruise but not in our spring cruise, when stages V and VIII were altogether absent and stages IX to XI very scarce. The year-round reproduction of P. guttatus is common in most of its geographic range [83,84], with individual females spawning three to four times per year [85]. However, unlike P. argus, P. guttatus is a rather small lobster restricted to the coral reef habitat throughout its benthic life and a minor fishing resource in only a few locations $[76,86,87]$. Moreover, its average larval duration, estimated in culture at 410 days ( 13.6 months) [18], is among the longest within the genus Panulirus. According to Goldstein et al. [18], such a long larval duration may be a strategy to avoid sub-optimal conditions or settlement sites before attaining larval competency. However, our results suggest that a potential trade-off of this strategy could be a wider temporal variation in larval abundance, especially of the late stages.

The other three palinurids present in our samples were far less abundant, and data on their biology are also very scarce. Palinurellus gundlachi is a small, highly cryptic coraldwelling lobster that occurs down to about $35 \mathrm{~m}$ in depth [9], whereas Justitia longimana occurs from $40 \mathrm{~m}$ to over $100 \mathrm{~m}$ in depth [88]. Larval stages II-X of J. longimana were described from plankton samples, but the larval duration has not been determined, although it would appear to be protracted [12]. Larval stages I-XII of P. gundlachi, with an estimated duration of 10 months, were also described from plankton samples [20]. Interestingly, we obtained more late- than mid-stage phyllosomata of P. gundlachi in both our cruises, and even several early-stage larvae in the spring cruise. However, there is no information on the reproductive activities of these two species with which to confront our findings. Panulirus laevicauda, an abundant species in Brazil [9], rarely occurs in the wider Caribbean region [89]. We only obtained three phyllosomata of $P$. laevicauda, two stage $\mathrm{X}$ and one that 
we ascribed to stage IX, and only four larvae of this species (in stages VI, VIII, X, and XI) had been previously obtained in the Caribbean Sea $[19,38]$.

\subsection{Scyllarids}

The family Scyllaridae has four subfamilies, of which three (Arctidinae, Ibacinae, and Scyllarinae) occur in the Atlantic [90]. Arctidinae (e.g., Scyllarides) and Ibacinae (e.g., Parribacus) are large slipper lobsters associated with complex coral reef habitats [8]. Both have long larval phases that develop in oceanic waters, much like palinurids. The complete larval development of S. aequinoctialis and P. antarcticus (comprising 11 and 12 stages, respectively) was described from a combination of wild and cultured larvae and was estimated at 8-9 months and 9 months, respectively [21-23]. We obtained more midthan late-stage phyllosomata of $S$. aequinoctialis in both cruises, especially in the autumn. Interestingly, P. antarcticus was the third most abundant species in our autumn cruise, with mostly mid-stage larvae, but was completely absent in our samples of the spring cruise. Unfortunately, almost nothing is known about the reproductive dynamics of these two scyllarids [91].

Scyllarinae (e.g., Scyllarus and Bathyarctus) are small slipper lobsters with relatively short larval phases that tend to develop in coastal and neritic waters [4]. Of the five species of Scyllarinae occurring in the western Caribbean, we only obtained the phyllosomata of one: Scyllarus chacei, mostly during the spring cruise and only the late stages. Early-stage larvae tentatively ascribed to this species had been previously reported in our study area but over shallower depths [39]. The larval duration of $S$. chacei has been estimated at only 44 days [15], suggesting an adaptation to enhance larval retention close to the parental populations [3]. The adults of $S$. chacei have a similar bathymetric distribution as those of S. depressus and S. planorbis ( 11-300 m, [8,92,93], whereas the adults of B. faxoni occur at even greater depths (229-457 m). Yet, we did not obtain the larvae of $S$. depressus or S. planorbis in our cruises (there is no knowledge on the larvae of B. faxoni). Whether this result reflects interspecific differences in the reproductive periods or in the horizontal or vertical distribution patterns of the larvae remains to be studied. Larvae of S. americanus, which were also absent in our samples, are very common in the Gulf of Mexico, with only one report in the Mexican Caribbean [37], reflecting the distribution of adult populations of this species from Massachusetts to the Gulf of Mexico [8].

\subsection{Phyllosomata Assemblages and Oceanographic Features}

Panulirus argus larvae overwhelmingly dominated the catch, but, by considering the mid- and late stages of each species as separate groups to analyze diversity indices and assemblage composition, interesting patterns emerged. For example, the higher values of diversity and evenness in the autumn and dominance in the spring reflect the proportionally greater abundance of mid-stage phyllosomata of $P$. argus in the spring cruise relative to the autumn cruise, the lower abundance of mid-stage phyllosomata of $P$. guttatus in the spring cruise relative to the autumn cruise, and the presence of both mid- and late stages of J. longimana and P. antarcticus in the autumn cruise but their absence in the spring cruise.

In contrast, the assemblage composition of phyllosomata did not vary much with the season. A few sampling stations had particularly different compositions (e.g., stations with few larvae but each of a different group vs. stations with many larvae of several different groups), but, in general, there was great overlap between the cruises. This result, in conjunction with the lack of a clear spatial pattern in the density distribution of these and the rest of the larval groups, suggests that there is extensive mixing of organisms upon becoming entrained in the strong Yucatan Current, which, during our cruises, had an average velocity of $1 \mathrm{~m} \mathrm{~s}^{-1}$ (see Figure 2) and was coherent down to $\sim 200 \mathrm{~m}$ in depth [48]. Oceanographic features play a significant role in the distribution of phyllosomata [68], and the Yucatan Current is clearly the main factor influencing the dispersion of these larvae in this region. However, although not evident in Figure 2, a coastal counter-current along 
the southern half of our study area and a persistent cyclonic sub-mesoscale eddy south of Cozumel Island were detected in both our cruises [48], and evidence of their existence was also found in previous studies [42,46,47]. These features may aid in the local, short-term retention of phyllosomata, as has been found for P. argus in the Florida Keys, USA [94] and for J. edwardsii in New Zealand [95,96], but probably cannot offset the highly advective environment of the Yucatan Current.

Around the Kuroshio Current in the northwest Pacific region, late stages of Panulirus japonicus have been reported at low densities of 0.1 to $0.5 \mathrm{ind} / 1000 \mathrm{~m}^{3}[97,98]$, much like the ones reported in the present study. Both the Kuroshio Current and the Yucatan Current are strong western boundary currents that increase the potential for the dispersion of phyllosomata through advection. Field studies [41,45] and biophysical modelling [28,33,34] suggest that the potential for the dispersion of larvae is greater in the northern half of the Mexican Caribbean area than in the Central America area, which has a more retentive oceanographic environment. Thus, for P. argus, the levels of genetic connectivity were higher in Central America than in the Mexican Caribbean [99]. Further north, in Florida, genetic studies and biophysical models $[32,35,46]$ have suggested that the local populations are highly dependent on the larval supply from more southern and southeastern populations.

The long larval duration of Achelata lobsters makes them particularly vulnerable to environmental variations and the effects of climate change because environmental conditions during the larval period affect the growth, survival, and dispersion of phyllosomata [68]. In the ocean, climate change involves increases in sea temperature and the intensity of ultraviolet radiation, as well as changes in circulation patterns, which may affect phyllosomata directly or indirectly $[100,101]$. For example, in the temperate East Australia Current, the phyllosomata of three tropical palinurid species are being transported by warm water eddies into temperate areas well outside the geographic range of the adult populations, providing them the opportunity to establish in such regions if environmental conditions become conducive to settlement [102]. Therefore, more field studies are needed to increase insight into the diversity and distribution of phyllosomata and their interaction with oceanographic processes that may influence the connectivity of lobster populations, and to understand how they might react to future environmental changes.

Author Contributions: Conceptualization, R.M.d.C.-H., P.B.-F. and E.L.-Á.; Data curation, R.M.d.C.-H., P.B.-F. and C.B.-O.; Formal analysis, R.M.d.C.-H. and P.B.-F.; Funding acquisition, P.B.-F.; Investigation, R.M.d.C.-H., P.B.-F., C.B.-O., F.N.-S. and E.L.-Á.; Methodology, R.M.d.C.-H., P.B.-F., C.B.-O., F.N.-S. and E.L.-Á.; Project administration, P.B.-F. and F.N.-S.; Resources, P.B.-F., F.N.-S. and E.L.-Á.; Supervision, P.B.-F. and E.L.-Á.; Validation, R.M.d.C.-H., P.B.-F. and C.B.-O.; Visualization, R.M.d.C.-H., P.B.-F. and E.L.-Á.; Writing—original draft, P.B.-F.; Writing—review \& editing, R.M.d.C.-H., P.B.-F., C.B.-O., F.N.-S. and E.L.-Á. All authors have read and agreed to the published version of the manuscript.

Funding: This research was funded by Consejo Nacional de Ciencia y Tecnología, México (CONACYT) through the provision of a grant (number CB-101200) to P.B.-F., and an M.Sc. scholarship to R.M.d.C.-H.

Institutional Review Board Statement: Not applicable.

Data Availability Statement: The data presented in this study are openly available at https://hdl. handle.net/20.500.12201/11335 (accessed on 13 September 2021).

Acknowledgments: We thank Captain L. Ríos-Mora and the crew of the R/V Justo Sierra, as well as E. Escalante-Mancera, C. A. Coronado-Méndez, A. F. Espinosa-Magaña, L. Carrillo, I. SeguraGarcía, J. P. Huchin-Mian, R. Candia-Zulbarán, R. Martínez-Calderón, N. Herrera-Salvatierra, C. Flores-Cabrera, J. M. Ojeda-Cota, A. Almazán-Becerril, S. Escobar-Morales, S. Martínez-Gomez, and M. Ortiz-Matamoros for their assistance during the oceanographic cruises. We also thank J. Candela for producing Figure 2.

Conflicts of Interest: The authors declare no conflict of interest. The funders had no role in the design of the study; in the collection, analyses, or interpretation of data; in the writing of the manuscript, or in the decision to publish the results. 


\section{Appendix A}

Table A1. Similarity measures within and between seasons (cruises). Analysis of similarity percentage (SIMPER) for phyllosomata assemblages within the autumn cruise and the spring cruise, and of dissimilarity percentage between cruises. Av.Abund: average abundance; Av.Sim: average similarity; Sim/SD: similarity/standard deviation; Contrib\%: contribution in \%; Cum\%: cumulative contribution in \%; Av.Diss: average dissimilarity; Diss/SD, dissimilarity/standard deviation.

\begin{tabular}{|c|c|c|c|c|c|c|}
\hline \multicolumn{7}{|c|}{ Autumn Cruise: Average Similarity: $45.94 \%$} \\
\hline Species & Av.Abund & Av.Sim & $\mathrm{Sim} / \mathrm{SD}$ & Contrib\% & Cum.\% & \\
\hline Panulirus argus mid-stages & 3.0 & 16.6 & 1.4 & 36.1 & 36.1 & \\
\hline Panulirus guttatus mid-stages & 2.1 & 11.3 & 1.2 & 24.6 & 60.7 & \\
\hline Panulirus argus late stages & 1.8 & 10.0 & 1.3 & 21.7 & 82.5 & \\
\hline P. guttatus late stages & 1.0 & 4.3 & 0.7 & 9.3 & 91.8 & \\
\hline \multicolumn{7}{|c|}{ Spring Cruise: Average Similarity: $44.36 \%$} \\
\hline Species & Av.Abund & Av.Sim & $\mathrm{Sim} / \mathrm{SD}$ & Contrib\% & Cum.\% & \\
\hline Panulirus argus mid-stages & 3.49 & 22.95 & 1.43 & 51.7 & 51.7 & \\
\hline Panulirus argus late stages & 1.74 & 8.26 & 0.86 & 18.6 & 70.4 & \\
\hline Panulirus guttatus mid-stages & 1.05 & 4.17 & 0.71 & 9.4 & 79.8 & \\
\hline Scyllarus chacei late stages & 0.7 & 3.35 & 0.39 & 7.6 & 87.3 & \\
\hline Palinurellus gundlachi late stages & 0.7 & 2.44 & 0.48 & 5.5 & 92.8 & \\
\hline \multicolumn{7}{|c|}{ Autumn and Spring Cruises: Average Dissimilarity $=59.68 \%$} \\
\hline Species & $\begin{array}{c}\text { Autumn } \\
\text { Av.Abund }\end{array}$ & $\begin{array}{c}\text { Spring } \\
\text { Av.Abund }\end{array}$ & Av.Diss & Diss/SD & Contrib\% & Cum.\% \\
\hline Panulirus argus mid-stages & 3.00 & 3.49 & 14.5 & 1.2 & 24.3 & 24.3 \\
\hline Panulirus argus late stages & 1.83 & 1.74 & 9.4 & 1.2 & 15.7 & 40.0 \\
\hline Panulirus guttatus mid-stages & 2.12 & 1.05 & 9.3 & 1.2 & 15.6 & 55.6 \\
\hline Panulirus guttatus late stages & 0.98 & 0.35 & 5.2 & 0.9 & 8.6 & 64.3 \\
\hline Scyllarus chacei late stages & 0.02 & 0.70 & 4.6 & 0.6 & 7.8 & 72.0 \\
\hline Palinurellus gundlachi late stages & 0.42 & 0.70 & 4.2 & 0.9 & 7.1 & 79.1 \\
\hline Scyllarides aequinoctialis mid-stages & 0.29 & 0.52 & 3.6 & 0.7 & 6.1 & 85.2 \\
\hline Parribacus antarcticus mid-stages & 0.52 & 0.00 & 2.7 & 0.6 & 4.5 & 89.7 \\
\hline Palinurellus gundlachi mid-stages & 0.11 & 0.34 & 1.9 & 0.6 & 3.2 & 92.9 \\
\hline
\end{tabular}

\section{References}

1. Chan, T.Y. Annotated checklist of the world's marine lobsters (Crustacea: Decapoda: Astacidea, Glypheidea, Achelata, Polychelida). Raffles Bull. Zool. 2010, 23, 153-181.

2. Chan, T.Y. Updated checklist of the world's marine lobsters. In Lobsters: Biology, Fisheries and Aquaculture; Radhakrishnan, E.V., Phillips, B.F., Achamveetil, G., Eds.; Springer: Singapore, 2019; pp. 35-64.

3. Booth, J.D.; Webber, W.R.; Sekiguchi, H.; Coutures, E. Diverse larval recruitment strategies within the Scyllaridae. N. Z. J. Mar. Freshw. Res. 2005, 39, 581-592. [CrossRef]

4. Sekiguchi, H.; Booth, J.D.; Webber, W.R. Early life histories of slipper lobsters. In The Biology and Fisheries of the Slipper Lobster; Lavalli, K.L., Spanier, E., Eds.; CRC Press: Boca Raton, FL, USA, 2007; pp. 69-86.

5. McWilliam, P.S.; Phillips, B.F. Metamorphosis of the final phyllosoma and secondary lecithotrophy in the puerulus of Panulirus cygnus George: A review. Mar. Freshw. Res. 1997, 48, 783-790. [CrossRef]

6. Booth, J.D.; Phillips, B.F. Early life history of spiny lobster. Crustaceana 1994, 66, 271-294.

7. Phillips, B.F.; McWilliam, P.S. Spiny lobster development: Where does successful metamorphosis to the puerulus occur? A review. Rev. Fish Biol. Fish. 2009, 19, 193-215. [CrossRef]

8. Lyons, W.G. Scyllarid lobsters (Crustacea, Decapoda). Mem. Hourglass Cruises 1970, 1, 1-74.

9. Holthuis, L.B. Marine Lobsters of the World; FAO Species Catalogue No. 13; FAO: Rome, Italy, 1991.

10. Lewis, J.B. The phyllosoma larvae of the spiny lobster Panulirus argus. Bull. Mar. Sci. Gulf Carib. 1951, 1, 89-103.

11. Goldstein, J.S.; Matsuda, H.; Takenouchi, T.; Butler, M.J., IV. The complete development of larval Caribbean spiny lobster Panulirus argus (Latreille, 1804) in culture. J. Crust. Biol. 2008, 28, 306-327. [CrossRef]

12. Robertson, P.B. Phyllosoma larvae of a palinurid lobster, Justitia longimana (H. Milne Edwards), from the western Atlantic. Bull. Mar. Sci. 1969, 19, 922-944.

13. Robertson, P.B. The complete larval development of the sand lobster, Scyllarus americanus (Smith) (Decapoda, Scyllaridae) in the laboratory, with notes on larvae from the plankton. Bull. Mar. Sci. 1968, 18, 294-342. 
14. Robertson, P.B. The larvae and postlarva of the scyllarid lobster Scyllarus depressus (Smith). Bull. Mar. Sci. 1971, 21, 841-865.

15. Robertson, P.B. The Larval Development of Some Western Atlantic Lobsters of the Family Scyllaridae. Ph.D. Thesis, University of Miami, Coral Gables, FL, USA, 1968.

16. Robertson, P.B. Larval development of the scyllarid lobster Scyllarus planorbis (Holthuis) reared in the laboratory. Bull. Mar. Sci. $1979,29,320-328$.

17. Baisre, J.A.; Alfonso, I. Later stage larvae of Panulirus guttatus (Latreille, 1804) (Decapoda, Palinuridae) with notes on the identification of phyllosomata of Panulirus in the Caribbean Sea. Crustaceana 1994, 66, 32-44. [CrossRef]

18. Goldstein, J.S.; Matsuda, H.; Matthews, T.R.; Fumihiko, A.; Yamakawa, T. Development in culture of larval spotted spiny lobster Panulirus guttatus (Latreille, 1804) (Decapoda: Achelata: Palinuridae). J. Crust. Biol. 2019, 39, 574-581. [CrossRef]

19. Baisre, J.A.; Ruiz de Quevedo, M.E. Two phyllosome larvae of Panulirus laevicauda (Latreille, 1817) (Decapoda, Palinuridae) from the Caribbean Sea with a discussion about larval groups within the genus. Crustaceana 1982, 43, 147-153. [CrossRef]

20. Sims, H.W., Jr. The phyllosoma larvae of the spiny lobster Palinurellus gundlachi von Martens (Decapoda, Palinuridae). Crustaceana 1966, 11, 205-215. [CrossRef]

21. Robertson, P.B. The early larval development of the scyllarid lobster Scyllarides aequinoctialis (Lund) in the laboratory, with a revision of the larval characters of the genus. Deep Sea Res. 1969, 16, 557-586. [CrossRef]

22. Sims, H.W., Jr. The phyllosoma larvae of Parribacus (Decapoda, Palinuridae). Quart. J. Florida Acad. Sci. 1965, $28,142-172$.

23. Johnson, M.W. The phyllosoma larvae of slipper lobsters from the Hawaiian Islands and adjacent areas (Decapoda, Scyllaridae). Crustaceana 1971, 20, 77-103. [CrossRef]

24. Ehrhardt, N.M.; Puga, R.; Butler, M.J., IV. Implications of the ecosystem approach to fisheries management in large ecosystems: The case of the Caribbean spiny lobster. In Towards Marine Ecosystem-Based Management in the Wider Caribbean; Fanning, L., Mahon, R., McConney, P., Eds.; Amsterdam University Press: Amsterdam, The Netherlands, 2011; pp. 157-175.

25. Shanks, A.L. Pelagic larval duration and dispersal distance revisited. Biol. Bull. 2009, 216, 373-385. [CrossRef]

26. Minami, H.; Inoue, N.; Sekiguchi, H. Vertical distribution of phyllosoma larvae of palinurid and scyllarid lobsters in the western North Pacific. J. Oceanogr. 2001, 57, 743-748. [CrossRef]

27. Bradford, R.W.; Bruce, B.D.; Chiswell, S.M.; Booth, J.D.; Jeffs, A.; Wotherspoon, S. Vertical distribution and diurnal migration patterns of Jasus edwardsii phyllosomas off the east coast of the North Island, New Zealand. N. Z. J. Mar. Freshw. Res. 2005, 39, 593-604. [CrossRef]

28. Butler, M.J., IV; Paris, C.B.; Goldstein, J.S.; Matsuda, H.; Cowen, R.K. Behavior constrains the dispersal of long-lived spiny lobster larvae. Mar. Ecol. Prog. Ser. 2011, 422, 223-237. [CrossRef]

29. Mishra, M.; Jeffs, A.; Meyer-Rochow, V.B. Eye structure of the phyllosoma larva of the rock lobster Jasus edwardsii (Hutton, 1875): How does it differ from that of the adult? Invertebr. Reprod. Dev. 2006, 49, 213-222. [CrossRef]

30. Funes-Rodríguez, R.; Ruíz-Chavarría, J.A.; González-Armas, R.; Durazo, R.; Guzmán-del Proó, S.A. Influence of hydrographic conditions on the distribution of spiny lobster larvae off the west coast of Baja California. Trans. Am. Fish. Soc. 2015, 144, 1192-1205. [CrossRef]

31. Snyder, E.R.; Paris, C.B.; Vaz, C.A. How much do marine connectivity fluctuations matter? Am. Nat. 2014, 184, 523-530. [CrossRef] [PubMed]

32. Segura-García, I.; Garavelli, L.; Tringali, M.; Matthews, T.; Chérubin, L.M.; Hunt, J.; Box, S.J. Reconstruction of larval origins based on genetic relatedness and biophysical modeling. Sci. Rep. 2019, 9, 7100. [CrossRef]

33. Briones-Fourzán, P.; Candela, J.; Lozano-Álvarez, E. Postlarval settlement of the spiny lobster Panulirus argus along the Caribbean coast of Mexico: Patterns, influence of physical factors, and possible sources of origin. Limnol. Oceanogr. 2008, 53, 970-985. [CrossRef]

34. Kough, A.S.; Paris, C.B.; Butler, M.J., IV. Larval connectivity and the international management of fisheries. PLoS ONE 2013, 8 , e64970. [CrossRef]

35. Lara-Hernández, J.A.; Zavala-Hidalgo, J.; Sanvicente-Añorve, L.; Briones-Fourzán, P. Connectivity and larval dispersal pathways of Panulirus argus in the Gulf of Mexico: A numerical study. J. Sea Res. 2019, 155, 101814. [CrossRef]

36. Saunders, M.I.; Thompson, P.A.; Jeffs, A.G.; Säwström, C.; Sachlikidis, N.; Beckley, L.E.; Waite, A.M. Fussy feeders: Phyllosoma larvae of the Western Rock lobster (Panulirus cygnus) demonstrate prey preference. PLoS ONE 2012, 7, e36580. [CrossRef]

37. Olvera-Limas, R.M.; Ordóñez-Alcalá, L. Distribución, abundancia relativa y desarrollo larvario de langostas Panulirus argus y Scyllarus americanus en la ZEE del Golfo de México y mar Caribe. Cienc. Pesq. 1988, 6, 7-31.

38. Manzanilla-Domínguez, H.; Gasca, R. Distribution and abundance of phyllosoma larvae (Decapoda, Palinuridae) in the southern Gulf of Mexico and the western Caribbean Sea. Crustaceana 2004, 77, 75-94.

39. Briones-Fourzán, P.; Lozano-Álvarez, E.; Monroy-Velázquez, L.V. Langostas Palinuroideas. In Camarones, Langostas y Cangrejos de la Costa Este de México; Hernández-Aguilera, J.L., Ruiz-Nuño, J.A., Toral-Almazán, R.E., Arenas-Fuentes, V., Eds.; CONABIO: Mexico City, Mexico, 2005; Volume 1, pp. 207-235.

40. Manzanilla-Domínguez, H.; Gasca, R.; Suárez-Morales, E. Notes on the distribution of phyllosoma larvae in an oceanic atoll-like reef system in the western Caribbean. Crustaceana 2005, 78, 505-512.

41. Canto-García, A.; Goldstein, J.; Sosa-Cordero, E.; Carrillo, L. Distribution and abundance of Panulirus spp. phyllosomas off the Mexican Caribbean coast. Bull. Mar. Sci. 2016, 92, 207-227. [CrossRef] 
42. Carrillo, L.; Largier, J.L.; Johns, E.; Smith, R.; Lamkin, J. Pathways and upper hydrography in the Mesoamerican Barrier Reef System-Part 1: Circulation. Contin. Shelf Res. 2015, 109, 164-176. [CrossRef]

43. Badan, A.; Candela, J.; Sheinbaum, J.; Ochoa, J. Upper-layer circulation in the approaches to Yucatan Channel. In Circulation in the Gulf of Mexico: Observations and Models; Geophysical Monograph Series 161; American Geophysical Union: Washington, DC, USA, 2005; pp. 57-69.

44. Cetina, P.; Candela, J.; Sheinbaum, J.; Ochoa, J.; Badam, A. Circulation along the Mexican Caribbean coast. J. Geophys. Res. 2006, 111, C08021. [CrossRef]

45. Muhling, B.A.; Smith, R.H.; Vázquez-Yeomans, L.; Lamkin, J.T.; Johns, E.M.; Carrillo, L.; Sosa-Cordero, E.; Malca, E. Larval fish assemblages and mesoscale oceanographic structure along the Mesoamerican Barrier Reef System. Fish. Oceanogr. 2013, 22, 409-428. [CrossRef]

46. Merino, M. Aspectos de la circulación costera superficial del Caribe mexicano con base en observaciones utilizando tarjetas de deriva. An. Inst. Cienc. del Mar y Limnol. Univ. Nal. Autón. México 1986, 13, 31-46.

47. Chávez, G.; Candela, J.; Ochoa, J. Subinertial flows and transports in Cozumel Channel. J. Geophys. Res. 2003, 108, 3037. [CrossRef]

48. Briones-Fourzán, P.; Candela, J.; Carrillo, L.; Espinosa-Magaña, A.; Negrete-Soto, F.; Barradas-Ortiz, C.; Escalante-Mancera, E.; Muñoz de Cote-Hernández, R.; Martínez-Calderón, R.; Lozano-Álvarez, E. Metamorphosis of spiny lobsters (Panulirus argus and Panulirus guttatus) in the Yucatan current as inferred from the distribution of pueruli and final stage phyllosomata. Limnol. Oceanogr. 2021, 66, 3421-3438. [CrossRef]

49. Lozano-Álvarez, E.; Briones-Fourzán, P.; Huchin-Mian, J.P.; Segura-García, I.; Ek-Huchim, J.P.; Améndola-Pimenta, M.; RodríguezCanul, R. Panulirus argus virus 1 detected in oceanic postlarvae of Caribbean spiny lobster: Implications for disease dispersal. Dis. Aquat. Org. 2015, 117, 165-170. [CrossRef]

50. Espinosa-Magaña, A.; Briones-Fourzán, P.; Jeffs, A.; Lozano-Álvarez, E. Energy cost of the onshore transport of postlarvae of the Caribbean spiny lobster. Bull. Mar. Sci. 2018, 94, 801-819. [CrossRef]

51. Briones-Fourzán, P.; Espinosa-Magaña, A.F.; Lozano-Álvarez, E.; Jeffs, A. Analysis of fatty acids to examine larval and settlement biology of the Caribbean spiny lobster Panulirus argus. Mar. Ecol. Prog. Ser. 2019, 630, 137-148. [CrossRef]

52. Rimmer, D.W.; Phillips, B.F. Diurnal migration and vertical distribution of phyllosoma larvae of the Western rock lobster Panulirus cygnus. Mar. Biol. 1979, 54, 109-124. [CrossRef]

53. Alfonso, I.; Frías, M.P.; Baisre, J. Distribución, abundancia y migración vertical de la fase larval de la langosta comercial Panulirus argus en aguas cubanas. Rev. Inv. Mar. 1999, 20, 23-32.

54. Yeung, C.; McGowan, M.F. Differences in inshore-offshore and vertical distribution of phyllosoma larvae of Panulirus, Scyllarus and Scyllarides in the Florida Keys in May-June, 1989. Bull. Mar. Sci. 1991, 49, 699-714.

55. Robertson, P.B. A giant phyllosoma larva from the Caribbean Sea, with notes on smaller specimens. Crustaceana 1968, 15 (Suppl. 2), 83-97.

56. Palero, F.; Guerao, G.; Hall, M.; Chan, T.Y.; Clark, P.F. The 'giant phyllosoma' are larval stages of Parribacus antarcticus (Decapoda: Scyllaridae). Invertebr. Syst. 2014, 28, 258-276. [CrossRef]

57. Phillips, B.F.; Rimmer, D.W.; Reid, D.D. Ecological investigations of the late-stage phyllosoma and puerulus larvae of the western rock lobster Panulirus longipes cygnus. Mar. Biol. 1978, 45, 347-357. [CrossRef]

58. Phillips, B.F.; Brown, P.A.; Rimmer, D.W.; Braine, S.J. Distribution and dispersal of the phyllosoma larvae of the western rock lobster Panulirus cygnus, in the south-eastern Indian Ocean. Aust. J. Mar. Freshw. Res. 1979, 30, 773-783. [CrossRef]

59. Mallol, S.; Mateo-Ramírez, A.; Alemany, F.; Álvarez-Berastegui, D.; Díaz, D.; López-Jurado, J.L.; Goñi, R. Abundance and distribution of scyllarid phyllosoma larvae (Decapoda: Scyllaridae) in the Balearic Sea (Western Mediterranean). J. Crust. Biol. 2014, 34, 442-452. [CrossRef]

60. Morris, E.K.; Caruso, T.; Buscot, F.; Fischer, M.; Hancock, C.; Maier, T.S.; Meiners, T.; Müller, C.; Obermaier, E.; Prati, D.; et al. Choosing and using diversity indices: Insights for ecological applications from the German Biodiversity Exploratories. Ecol. Evol. 2014, 4, 3514-3524. [CrossRef] [PubMed]

61. Phleger, C.F.; Nelson, M.M.; Mooney, B.D.; Nichols, P.D.; Ritar, A.J.; Smith, G.G.; Hart, P.R.; Jeffs, A.G. Lipids and nutrition of the southern rock lobster, Jasus edwardsii, from hatch to puerulus. Mar. Freshw. Res. 2001, 52, 1475-1486. [CrossRef]

62. Wang, M.; O’Rorke, R.; Waite, A.M.; Beckley, L.E.; Thompson, P.; Jeffs, A.G. Fatty acid profiles of phyllosoma larvae of western rock lobster (Panulirus cygnus) in cyclonic and anticyclonic eddies of the Leeuwin Current off Western Australia. Prog. Oceanogr. 2014, 122, 153-162. [CrossRef]

63. Sánchez, A.; Gasca, R.; Sosa-Cordero, E.; Camacho-Cruz, K. Stable carbon and nitrogen isotopes in Panulirus argus phyllosomas in the Mexican Caribbean. Reg. Stud. Mar. Sci. 2021, 42, 101617. [CrossRef]

64. Clarke, K.R. Non-parametric multivariate analyses of changes in community structure. Aust. J. Ecol. 1993, 18, 117-143. [CrossRef]

65. Clarke, K.R.; Warwick, R.M. Change in Marine Communities: An Approach to Statistical Analysis and Anterpretation, 2nd ed.; PRIMER-E: Plymouth, UK, 2001.

66. Clarke, K.R.; Gorley, R.N. PRIMER v6: User/Manual Tutorial; PRIMER-E: Plymouth, UK, 2006.

67. Hammer, Ø.; Harper, D.A.T.; Ryan, P.D. PAST: Paleontological statistics software package for education and data analysis. Palaeontol. Electron. 2001, 4, 1-9.

68. Phillips, B.F.; Booth, J.D.; Stanley, J.C.; Jeffs, A.G.; McWilliam, P. Larval and postlarval ecology. In Lobsters: Biology, Management, Aquaculture and Fisheries; Phillips, B.F., Ed.; Blackwell: Oxford, UK, 2006; pp. 231-235. 
69. Johnson, M.W. Production and distribution of larvae of the spiny lobster Panulirus interruptus (Randall) with records on P. gracilis (Streets). Bull. Scripps Inst. Oceanogr. 1960, 7, 412-461.

70. Lazarus, B.I. The occurrence of phyllosomata off the Cape with particular reference to Jasus lalandii. S. Afr. Div. Sea Fish. Invest. Rep. 1967, 63, 1-38.

71. Lesser, J.H.R. Phyllosoma larvae of Jasus edwardsii (Hutton) (Crustacea: Decapoda: Palinuridae) and their distribution off the east coast of the North Island, New Zealand. N. Z. J. Mar. Freshw. Res. 1978, 12, 357-370. [CrossRef]

72. Inoue, N.; Minami, H.; Sekiguchi, H. Distribution of phyllosoma larvae (Crustacea: Decapoda: Palinuridae, Scyllaridae and Synaxidae) in the western north Pacific. J. Oceanogr. 2004, 60, 963-976. [CrossRef]

73. Johnson, M.J. The palinurid and scyllarid lobster larvae of the tropical eastern Pacific and their distribution as related to the prevailing hydrography. Bull. Scripps Inst. Oceanogr. 1971, 19, 1-36.

74. Sims, H.W., Jr.; Ingle, R.M. Caribbean recruitment of Florida's spiny lobster population. Quart. J. Florida Acad. Sci. 1966, 29, 207-242.

75. Yeung, C.; Jones, D.L.; Criales, M.M.; Jackson, T.L.; Richards, W.J. Influence of coastal eddies and counter-currents on the influx of spiny lobster, Panulirus argus, postlarvae into Florida Bay. Mar. Freshw. Res. 2001, 52, 1217-1232. [CrossRef]

76. Briones-Fourzán, P.; Lozano-Álvarez, E. Essential habitats for Panulirus spiny lobsters. In Lobsters: Biology, Management, Aquaculture and Fisheries, 2nd ed.; Phillips, B.F., Ed.; Wiley-Blackwell: Oxford, UK, 2013; pp. 186-220.

77. Bertelsen, R.D.; Matthews, T.R. Fecundity dynamics of female spiny lobster (Panulirus argus) in a south Florida fishery and Dry Tortugas National Park lobster sanctuary. Mar. Freshw. Res. 2001, 52, 1559-1565. [CrossRef]

78. Fonseca-Larios, M.E.; Briones-Fourzán, P. Fecundity of the spiny lobster Panulirus argus (Latreille, 1804) in the Caribbean coast of Mexico. Bull. Mar. Sci. 1998, 63, 21-32.

79. Castillo, A.; Lessios, H.A. Lobster fishery by the Kuna Indians in the San Blas Region of Panama (Kuna Yala). Crustaceana 2001, $74,459-475$.

80. Yallonardo, M.; Posada, J.M.; Schweizer, D.M. Current status of the spiny lobster, Panulirus argus, fishery in the Los Roques Archipelago National Park, Venezuela. Mar. Freshw. Res. 2001, 52, 1615-1622. [CrossRef]

81. Martínez-Calderón, R.; Lozano-Álvarez, E.; Briones-Fourzán, P. Morphometric relationships and seasonal variation in size, weight, and a condition index of post-settlement stages of the Caribbean spiny lobster. PeerJ 2018, 6, e5297. [CrossRef]

82. Matsuda, H.; Yamakawa, T. Effects of temperature on growth of the Japanese spiny lobster, Panulirus japonicus phyllosomas under laboratory conditions. Mar. Freshw. Res. 1997, 48, 791-796. [CrossRef]

83. Marfin, J.P. Biologie et pêche de la langouste Panulirus guttatus en Martinique. Sci. Pêche 1978, 278, 1-10.

84. Sharp, W.C.; Hunt, J.H.; Lyons, W.G. Life history of the spotted spiny lobster, Panulirus guttatus, an obligate reef-dweller. Mar. Freshw. Res. 1997, 28, 142-172. [CrossRef]

85. Briones-Fourzán, P.; Contreras-Ortiz, G. Reproduction of the spiny lobster Panulirus guttatus (Decapoda: Palinuridae) on the Caribbean Coast of Mexico. J. Crust. Biol. 1999, 19, 171-179. [CrossRef]

86. Losada-Tostesón, V.; Posada, J.M.; Losada, F. Size and reproductive status of fished spotted spiny lobster, Panulirus guttatus, in Morrocoy National Park, Venezuela: A preliminary report. Mar. Freshw. Res. 2001, 52, 1599-1603. [CrossRef]

87. Wynne, S.; Côté, I. Effects of habitat quality and fishing on Caribbean spotted spiny lobster populations. J. Appl. Ecol. 2007, 44, 488-494. [CrossRef]

88. Monod, T.; Postel, E. Notes sur une langouste brévicorne peu connue, Justitia longimana (H. Milne Edwards). Crustaceana 1968, 14, 178-184. [CrossRef]

89. Briones-Fourzán, P.; Barradas-Ortiz, C.; Negrete-Soto, F.; Segura-García, I.; Lozano-Álvarez, E. Occurrence of Panulirus meripurpuratus and P. laevicauda (Decapoda: Achelata: Palinuridae) in Bahía de la Ascensión, Mexico. Lat. Am. J. Aquat. Res. 2019, 47, 694-698.

90. Webber, W.R.; Booth, J.D. Taxonomy and evolution. In The Biology and Fisheries of the Slipper Lobster; Lavalli, K.L., Spanier, E., Eds.; CRC Press: Boca Raton, FL, USA, 2007; pp. 25-52.

91. Sharp, W.C.; Hunt, J.H.; Teehan, W.H. Observations on the ecology of Scyllarides aequinoctialis, Scyllarides nodifer, and Parribacus antarcticus and a description of the Florida scyllarid lobster fishery. In The Biology and Fisheries of the Slipper Lobster; Lavalli, K.L., Spanier, E., Eds.; CRC Press: Boca Raton, FL, USA, 2007; pp. 231-242.

92. Holthuis, L.B. Biological investigations of the deep sea. 42. A new species of shovel-nose lobster, Scyllarus planorbis, from the southwestern Caribbean and northern South America. Bull. Mar. Sci. 1969, 19, 149-158.

93. Navas, G.R.; Campos, N.H. Las langostas chinas (Crustacea: Decapoda: Scyllaridae) del Caribe colombiano. Bol. Invest. Mar. Cost. 1998, 27, 51-66. [CrossRef]

94. Yeung, C.; Lee, T.E. Larval transport and retention of the spiny lobster, Panulirus argus, in the coastal zone of the Florida Keys, USA. Fish. Oceanogr. 2002, 11, 286-309. [CrossRef]

95. Chiswell, S.M.; Booth, J.D. Rock lobster Jasus edwardsii larval retention by the Wairarapa Eddy off New Zealand. Mar. Ecol. Prog. Ser. 1999, 183, 227-240. [CrossRef]

96. Chiswell, S.M.; Booth, J.D. Distribution of mid- and late-stage Jasus edwardsii phyllosomas: Implications for larval recruitment processes. N. Z. J. Mar. Freshw. Res. 2005, 39, 1157-1170. [CrossRef]

97. Yoshimura, T.; Yamakawa, H.; Kozasa, E. Distribution of final stage phyllosoma larvae and free-swimming pueruli of Panulirus japonicus around the Kuroshio Current off southern Kyusyu, Japan. Mar. Biol. 1999, 133, 293-306. [CrossRef] 
98. Inoue, N.; Sekiguchi, H. Distribution of late-stage phyllosoma larvae of Panulirus japonicus in the Kuroshio Subgyre. Mar. Freshw. Res. 2001, 52, 1201-1209. [CrossRef]

99. Truelove, N.K.; Griffiths, S.; Ley-Cooper, K.; Azueta, J.; Majil, I.; Box, S.J.; Behringer, D.C.; Butler, M.J., IV; Preziosi, R.F. Genetic evidence from the spiny lobster fishery supports international cooperation among Central American marine protected areas. Conserv. Genet. 2015, 16, 347-358. [CrossRef]

100. Caputi, N.; de Lestang, S.; Frusher, S.; Wahle, R.A. The impact of climate change on exploited lobster stocks. In Lobsters: Biology, Management, Aquaculture and Fisheries, 2nd ed.; Phillips, B.F., Ed.; Wiley-Blackwell: Oxford, UK, 2013; pp. 84-112.

101. Phillips, B.F.; Pérez-Ramírez, M.; de Lestang, S. Lobsters in a changing climate. In Climate Change Impact on Fisheries and Aquaculture: A Global Analysis; Phillips, B.F., Pérez-Ramírez, M., Eds.; Wiley-Blackwell: Hoboken, NJ, USA, 2018 ; pp. 815-849.

102. Woodings, L.N.; Murphy, N.P.; Jeffs, A.; Suthers, I.M.; Liggins, G.W.; Strugnell, J.M. Distribution of Palinuridae and Scyllaridae phyllosoma larvae within the East Australian Current: A climate change hot spot. Mar. Freshw. Res. 2019, 70, 1020-1033. [CrossRef] 